NBER WORKING PAPER SERIES

INTERNATIONAL HAPPINESS

David G. Blanchflower

Andrew J. Oswald

Working Paper 16668

http://www.nber.org/papers/w16668

\author{
NATIONAL BUREAU OF ECONOMIC RESEARCH \\ 1050 Massachusetts Avenue \\ Cambridge, MA 02138 \\ January 2011
}

For suggestions and valuable discussions, we thank Gordon D.A. Brown, Rafael Di Tella, Amanda Goodall, Robert MacCulloch, Nick Powdthavee, Eugenio Proto, Daniel Sgroi, and Steve Wu. The views expressed herein are those of the authors and do not necessarily reflect the views of the National Bureau of Economic Research.

NBER working papers are circulated for discussion and comment purposes. They have not been peerreviewed or been subject to the review by the NBER Board of Directors that accompanies official NBER publications.

(C) 2011 by David G. Blanchflower and Andrew J. Oswald. All rights reserved. Short sections of text, not to exceed two paragraphs, may be quoted without explicit permission provided that full credit, including $\odot$ notice, is given to the source. 
International Happiness

David G. Blanchflower and Andrew J. Oswald

NBER Working Paper No. 16668

January 2011

JEL No. I1,I3

\section{ABSTRACT}

This paper describes the findings from a new, and intrinsically interdisciplinary, literature on happiness and human well-being. The paper focuses on international evidence. We report the patterns in modern data; we discuss what has been persuasively established and what has not; we suggest paths for future research. Looking ahead, our instinct is that this social-science research avenue will gradually merge with a related literature -- from the medical, epidemiological, and biological sciences -- on biomarkers and health. Nevertheless, we expect that intellectual convergence to happen slowly.

David G. Blanchflower

Bruce V. Rauner Professor of Economics

6106 Rockefeller Hall

Dartmouth College

Hanover, NH 03755-3514

and NBER

David.G.Blanchflower@Dartmouth.EDU

Andrew J. Oswald

Department of Economics

University of Warwick

Coventry CV4 7AL

England

a.j.oswald@warwick.ac.uk 


\title{
International Happiness
}

David G. Blanchflower

Andrew J. Oswald

\begin{abstract}
"Measures of both objective and subjective well-being provide key information about people's quality of life. Statistical offices should incorporate questions to capture people's life evaluations, hedonic experiences and priorities ..."

Stiglitz et al, Commission on the Measurement of Economic Performance and Social Progress, 2009.
\end{abstract}

\section{Introduction}

Standard indices of a country's prosperity -- such as longevity, human height, the incidence of disease, the suicide rate, and the level of Gross Domestic Product -- are well-known and widely collected. Governments throughout the developed nations, and in many developing nations, regularly publish such numbers. Yet if they are to do their job effectively, politicians and policy-makers arguably have to go beyond this. They have to try to understand, and measure, the happiness and mental health of their country's citizens. The reason is that it is overall human well-being (not simply a collection of its constituent elements) that is ultimately of interest.

The last few decades have seen a body of researchers attempt to rise to the difficult challenge of how to study 'happiness' in a systematic, empirical way. These scholars come from a range of disciplines -- including psychology, economics, epidemiology, medicine, statistics, sociology, political science, and management science. Although their methodological approaches differ in detail (moreover, researchers in one discipline are not always good at citing related work in the journals of the other disciplines, so different sub-fields sometimes lay claim to having discovered results first), a common methodology has begun to emerge.

This article describes the core findings from the new 'happiness' literature. ${ }^{1}$ One approach for a paper of this kind would be to go through in the manner of a survey article --

\footnotetext{
${ }^{1}$ Contributions from psychologists, economists, and other investigators, include Easterlin (1974), Clark and Oswald (1994), Diener et al (1995a,b), Ng (1997), Oswald (1997), Judge et al (1998), Veenhoven (1999), Argyle (2001), Di
} 
listing which researcher said what, and the year they said it. Here we take a different pedagogical approach. We hope it will be helpful for a starting reader who knows little about the field. In this paper, we take the latest international data and, using the methodological insights from the literature, build up from first principles to try to show readers how conclusions are reached in this field.

Most researchers begin from the idea that inside a human being there is some 'happiness' or utility function of general form:

Happiness = f(age, gender, income, education, marital status, diet, other personal characteristics, region characteristics, country characteristics)

It then draws upon quantitative methods that are formally similar to those employed in medical statistics, econometrics, and quantitative management science. Authors typically take a random sample of the population; they use multiple-regression techniques; some form of well-being measure is taken as the dependent variable in these equations; researchers calculate the size of the coefficients within so-called 'happiness equations' (Powdthavee 2010 is a valuable nontechnical guide to this). At a formal level, this method is like the approach of an epidemiologist who wishes to understand the myriad influences on a person's chance of good or bad life outcomes such as getting cancer. In both literatures -- epidemiology research and happiness research -- the outcome of such research is a linear or logistic equation in which factors like a person's age, gender, diet and smoking are shown statistically to matter.

Tella (2001), Radcliff (2001), Frey and Stutzer (2002), Easterlin (2003), Huppert and Whittington (2003), Blanchflower and Oswald (2004), Kahneman et al (2004), Van Praag and Ferrer-I-Carbonell 2004, Graham (2005), Luttmer (2005), Smith et al (2005), Steptoe et al (2005), Gilbert (2006), Welsch (2006), Grant et al (2007), Dolan et al (2008), Napier and Jost (2008), Powdthavee (2008), Stevenson and Wolfers (2008), Daly and Wilson (2009), Daly et al (2010), Devoe and Pfeffer (2009), Luechinger (2009), Judge et al (2010), Pittau et al (2010), Powdthavee (2010), Pfeffer (2010), Stone et al (2010), Bell and Blanchflower (2010), Kahneman and Deaton (2010), Blanchflower (2011) and Oswald and Wu (2011). A historian's perspective is provided by Offer (2006). 
Is happiness actually measurable? It is likely that debates about the right interpretation of subjective measures will continue throughout the $21^{\text {st }}$ century and beyond. But in social science they currently do so in a less strident way than decades earlier. Frey and Stutzer (2002) summarize ways to validate 'happiness' data. Krueger and Schkade (2008) show that people's reported well-being numbers are reasonably stable through time. Oswald and $\mathrm{Wu}$ (2010) demonstrate that across the states of the USA there is a strong match between subjective and objective well-being. ${ }^{2}$

What is noticeable about this line of modern social-science research is not merely the discoveries that have been made but the attention that such work has garnered outside academia. People seem to be attracted to the topic. Hundreds of recent newspaper articles have appeared discussing 'happiness research'. There are a number of popular science-of-happiness books and the Christmas edition of the latest (December 2010) issue of The Economist magazine features this research area on its cover. Politicians of left and right have shown interest, and a recent Commission led by Joseph Stiglitz and Amartya Sen produced a long report making recommendations on how, looking to the future of the industrialized nations, we might move away from simple GDP measurement.

Our own work in this field began in the early 1990s. We then had a connection with the London School of Economics; a third member there, Andrew E. Clark, also did early (and important) work within the same broad grouping. At that time, there was no interest from our colleagues in economics departments around the world, and at one infamous open conference in 1993 in London the three of us made up a fair proportion of the inhabitants of a large room of

\footnotetext{
${ }^{2}$ For the extreme sceptic, who is doubtful of all subjective statements in settings where humans may not wish to admit to shortcomings, one demonstration of the perhaps surprising accuracy of subjective assessments is given in Oswald (2010), which reports that data on subjective height (I am very tall...very short) are closely correlated with an objective feet-and-inches measure.
} 
empty chairs. At that juncture, virtually all economists viewed such work as misguided. One long paper, on well-being over time in Britain and the USA, took a decade to get published. There was precedent for all this: the seminal work of Richard Easterlin (1974, and later) had, years before, met with even less success.

Easterlin, whom we were later to meet in the late 1990s, had in the 1970s demonstrated that U.S. happiness did not seem to be rising through time with GDP growth. ${ }^{3}$ He had argued -and still does -- that the likely reason was that humans are fundamentally creatures of comparison; so that when they see everyone around them becoming richer at the same time as they themselves do the net result is a kind of generalized neutrality. We go from having one Ford to having three Lexuses, and nobody is happier. Many researchers believe in some version of this idea - that utility depends on relative factors. Such an approach goes back to, for example, Duesenberry's relative-income hypothesis (1949). Recent writings on comparisons includes Hagerty (2000), Luttmer (2005), Fliessbach (2007), Clark and Senik (2010), Daly et al (2010), and Layard (2010). In its latest incarnation, some authors have begun to argue empirically that ordinal rank may be what matters to humans (Brown et al 2008 review the evidence).

Despite economists' slowness to follow in Easterlin's footsteps, today -- at the time of writing late in 2010 -- this field within economics and social science has become one of the most quickly growing. Clark et al (2008) provides an introduction.

3 Not everyone agrees on Easterlin's paradox more broadly, even though there is agreement on the US evidence; see for example Stevenson and Wolfers (2008). A related modern literature finds evidence that mental strain may actually be worsening through time. Relevant work includes Sacker and Wiggins (2002), Green and Tsitsianis (2005), Hodiamont et al (2005), Green (2006), Oswald and Powdthavee (2007), and Oswald (2010). Research that looks at epidemiological measures of psychological well-being such as so-called GHQ scores includes Clark and Oswald (1994), Goldberg et al (1997), and Hu et al (2007). 
In this essay we touch on four themes: (i) we review the literature about what has been found in happiness research that seems true in almost all countries and is of particular interest to social scientists and management scholars; (ii) this includes issues such as which countries come out high, and which low, in happiness and well-being? (iii) what is wrong with existing approaches and why the use of national happiness is an improvement over GDP; (iv) how can the field do better, and where will research go?

The paper also discusses, and is motivated in part by, the recent Stiglitz Commission's report on the measurement of economic and social progress in a modern economy. This report, which may not yet be known to many management scholars or social scientists, was published in 2009 and can be downloaded from www.stiglitz-sen-fitoussi.fr. The Commission was set up by Nicholas Sarkozy of France.

\section{An Introduction to the Empirical Findings}

To get a feel for some of the discoveries in the happiness literature, consider Table 1, which uses the most up-to-date data available to us. It takes data on 48,000 individuals from the General Social Surveys of the United States, which since 1972 has been asking an annual random sample of Americans the question: Taken all together, how would you say things are these days: would you say that you are very happy (approximately 32\% give this answer), pretty happy (56\%), or not too happy (12\%)? So the vast majority of respondents are quite happy or very happy, and this is a consistent finding in the literature.

Table 1 presents a regression equation that is typical of the kind estimated in the happiness literature. It has as its dependent variable a cardinal version of people's answers, where 'very happy' is coded 3, 'pretty happy' is coded 2, and 'not too happy' is coded 1 . The mean level of American happiness -- given this elementary cardinal numbering -- is 2.2 with 
standard deviation 0.6. Statistically, this approach is not ideal (an ordinal estimator, such as ordered logistic regression, is preferable); the reason is that there are not good grounds to believe that people's happiness answers obey the rules of a cardinal scale. However, a long line of research papers has found that it makes little difference whether a cardinal or ordinal estimator is used, and the former method has the attractive feature that it is straightforward for readers to read off the size of effects in a regression equation. For ease of exposition in a review paper such as this, we use cardinal dependent variables throughout.

In Table 1, we find that American happiness:

- Is U-shaped through a person's lifespan (because Age enters, at the top of Table 1, with a quadratic shape)

- Is higher among those who are women (because Male enters with a negative coefficient of -0.0497)

- Is higher among whites, the highly educated, full-time workers, married people, and those on a high income.

- Is lower among those not in these categories or who are unemployed or temporarily not working, those who work at home, people who are widowed, divorced and separated, and those who had parents who divorced before they as children were 16 years old.

These judgments are from pooled cross-section analysis, so they describe associations in the data. We should be cautious before imputing causality into such patterns, but perhaps not so cautious that we turn a Nelson-like eye away from all such inferences. The famous and vital finding that smoking causes cancer was first observed as an elementary pattern in cross-sectional data. Moreover, those (often non-quantitative) researchers who are keen to remind us all that correlation is not causation should, in turn, occasionally be reminded that the discovery of a 
correlation is typically one necessary part of a proof of causation. Causation first needs correlation.

Table 1 allows the size of different influences to be seen. The age and age squared coefficients reveal that Americans' happiness reaches its low point at, on average, around 40 years old. The coefficient of -0.0497 on Male means that on average a woman reports a happiness level approximately 0.05 points higher than a man (on a scale that runs from 1.0 to 3.0). Similarly, reading down the first column of Table 1, black Americans report lower happiness than whites by approximately 0.13 points. A time trend enters negatively but, in this first column, in a way that is insignificantly different from zero. Years of schooling (i.e. the amount of education) enters strongly positively. The more educated that people are, the more they report a high score on a happiness scale.

According to the first column of Table 1, each extra year of education in the United States is associated with 0.017 extra happiness points, so that the difference, for example, between completing high school and completing a college degree is slightly greater than 0.06 happiness points. One of the (strikingly) large effects can be seen for the consequences of unemployment for happiness. Joblessness is associated here with a huge amount of unhappiness. Here, in Table 1's first column, there is a coefficient of -0.2343 (with a t-statistic of 14.1), which is almost twice that associated with the black dummy variable or five times that associated with being male. The other particularly large coefficient is on marriage, of 0.2322 . Hence married Americans are happier, ceteris paribus, by approximately one quarter of a happiness point on the 1-3 scale. 'Separated' is large and negative; it has a coefficient slightly exceeding -0.14. A parental-divorce variable, which measures whether the respondent at the age of sixteen lived with only one parent because they parents who were divorced, also enters 
negatively and with a tightly-defined standard error; its coefficient in the first column of Table 1 is -0.0436. It seems that it could be argued that American adults -- filling up their happiness forms many years after the event -- may carry a small psychological scar from parental divorce that occurred decades earlier. Again, this pattern may or may not be one of cause-and-effect.

Are richer Americans happier than poorer ones? Most economists, and many ordinary citizens, would think the answer is obvious: people strive after money so it must make them happier. Historically, there has been a huge debate on this topic in psychology journals.

Some textbooks -- we deliberately omit citations on this -- have wrongly told generations of psychology undergraduates that money is not a source of happiness. In so far as regression equations can settle the question, the answer is unambiguous: yes, money buys happiness. Every extra thousand dollars of income is associated, according to column 2 of Table 1, with 0.00246 extra units of happiness. Hence $\$ 100,000$ a year, for example, is the equivalent of 0.246 happiness points on the standardized GSS scale, which is slightly greater in size than the positive happiness value of marriage or the (negative) value of unemployment.

Recent work by Kahneman and Deaton (2010) has raised doubts about whether all measures of well-being are strictly increasing in income. A great deal of future research can be expected on this important issue.

Although it looks strange at first sight, in principle these statistical methods allow researchers to work out in an exact way the deep determinants of human well-being: they allow us to put a price tag on the happiness value of a host of life's influences. This is what the research literature has done. Much remains to be learned. But such valuations are now entering use in the ecological economics literature for the study of the environment, and may be close to being tested in the courts (where for a long time the value of emotional damages has been 
assigned, by judges and juries, by using intuition rather than formal techniques). We return to this later in the essay.

It might be believed, on the basis of Table 1, that the explanatory power of happiness equations is low. First, the R-squared values in Table 1 are below 0.1 , which implies that less than ten percent of the variance of reported happiness has been explained by the independent variables. Second, when compared to the size of one standard deviation of Americans' reported happiness (which is 0.635 ), the coefficients on most of these variables look small. But such an attitude may the wrong one. A more appropriate test is on the size and statistical significance of the coefficients on the independent variables. Again an epidemiological example may be appropriate: the R-squared on equations predicting who gets any disease is very small, but since the 1950s it has been usefully realized that diet and smoking enter with substantial and statistically significant coefficients.

A fundamental question, for both social science and public policy, is whether the quality of life in a country like the United States is improving through the years. What do the data say? They do not paint a particularly encouraging picture.

Table 2 describes the mean level of happiness in the USA in approximately every year between 1972 and 2008 (the most recent year for which data are available). As can be seen, just by inspection from Table 2 and without the need for statistical methods, Americans' happiness is not rising. In the early to mid 1970 s, one third of people said they were very happy with life; by the mid to late 2000s, that level of reported happiness was the same as, or, if anything, a little lower than, three decades earlier.

It might be thought that this is open to a killer objection. Perhaps humans will always renorm their answers as the years pass, which would make trends impossible. But the evidence 
does not greatly support such a view. For example, it is known that American women have become steadily less happy through time (Blanchflower and Oswald 2004, Stevenson and Wolfers 2009).

A more detailed kind of well-being equation is given in Table 3. In this case, the sample size is larger, at approximately one third of a million Americans in year 2009 (using the Behavioral Response Factor Surveillance System, organized by the CDC, the American Centers for Disease Control). Two well-being variables are available in BRFSS data: life satisfaction and reported days of bad mental health. The questions' wordings are, respectively,

"In general, how satisfied are you with your life?" Here people are able to answer one of the following: Very Satisfied, Satisfied, Dissatisfied, or Very Dissatisfied.

"Thinking about your mental health, which includes stress, depression, and problems with emotions, for how many days during the past 30 days was your mental health not good?"

The means (SDs) for these are 3.37 (0.63) and 3.35 (7.68).

Because of the large sample size, it is possible in the well-being regression equations of Table 3 to examine the statistical links between feelings of well-being and many of life's influences, such as, among others:

Taking exercise (positive for well-being),

Being male (negative),

Native American (negative),

Children in the household (negative),

Living as married (positive, though smaller than for marriage),

Self-employment (positive, once income is held constant),

Body mass index BMI (negative), 
Eating fruit and vegetables (positive),

Smoking (negative).

Here, as in the Table 1 results, which used GSS data, there is a marked positive association in Table 3 between income and psychological well-being. Because the relationship between utility and income is so fundamental to economics (and parts of management science and psychology), it is illuminating to study what is implied by the income coefficients in the lower part of the first column of Table 3. For example, the life-satisfaction coefficients rise from 0.0883 for the average level of American income (of between $\$ 20,000-\$ 25,000$ ) to 0.3044 for the higher income band of over $\$ 75,000$ a year. This is a (major) difference of approximately 0.22 life-satisfaction points. It corresponds in size to the difference in life satisfaction between being married and been single, and is nearly as large in absolute size as the consequences for well-being of being unemployed. Thus, as a matter of correlation, it appears that money buys 'happiness', and not in negligible quantities.

What is the link, in the United States, between education and life satisfaction? Here, the first two columns of Table 3 seem particularly interesting. In column 1, where there is no control for the level of income, life satisfaction is higher the higher is a person's level of education. But in column 2 of Table 3 that disappears: there are then no statistically significant effects from the education variables.

This is not as paradoxical as might initially be thought. What happens, in moving between column 1 and column 2 of Table 3, is that the statistical significance switches from education to income. The latter variables start to work strongly; yet the coefficient on College Graduate now drops to 0.0221 (with a t-statistic of only 0.74 ). Hence the extra satisfaction in life that is associated with greater education is, according to these US equations in Table 3, 
coming solely from the extra income that education brings. Interestingly, the coefficient on the black demographic variable is positive here, in Table 3 for the modern BRFSS data; whereas it was negative in our earlier GSS results. That is not easily explained but is consistent with the possibility that racial discrimination has declined.

The two right-hand columns of Table 3 give the findings for an alternative well-being variable, 'Days of bad mental health' in the previous month, where survey respondents can in the survey give answers from 0 (no days) to 30 (every day). This variable might be thought of as a crude measure of mental strain or depression. Most of the coefficients enter with a sign consistent with that in the life-satisfaction equation of Table 3. The only clear exception is for Male. Men are less satisfied on average, but also have fewer bouts of poor mental health. It is known from the psychiatry literature that females seem to suffer mental health problems more than males. A possible reconciliation of these -- seemingly contradictory -- facts is that women may be happier on average than men but also have a psychological-illness distribution that is more skewed to extreme values.

\section{Well-being across Different Countries in the World}

One of the interesting facts about recent happiness research is how its empirical findings have been to found to generalize across countries. ${ }^{4}$ To illustrate that, Table 4 moves to international data. It sets out European well-being regression equations. The sample size is approximately 35,000 randomly selected individuals across 31 nations (from Austria to Macedonia in Table 4, where Austria is the base country against which comparisons are made)

\footnotetext{
4 Published articles on international evidence include Stack and Eshelman (1998), Lester (2002), Schyns (2002), Steel and Ones (2002), Hagerty and Veenhoven (2003), Fahey and Smyth (2004), Powdthavee (2005), Bray and Gunnell (2006), the tongue-in-cheek Christensen et al (2006), Vemuri and Constanza (2006), Blanchflower (2001, 2009, 2011), Appleton and Song (2008), Deaton (2008), Diener et al (2008), Howell and Howell (2008), Rehdanz and Maddison (2008), Diener et al (2010),
} 
using data taken from the 2007 European Quality of Life Survey. Using these data, both happiness and life-satisfaction equations can be estimated.

We learn at least three things from Table 4. One is that the statistical structure of wellbeing in the European nations looks almost exactly the same as in the United States. The same variables enter, and in almost identical ways (to see this, compare Table 4 against the earlier Table 3). It may be this robustness that has stimulated so much recent happiness work of the same kind; researchers in country $\mathrm{Y}$ have found, once they started to interrogate their own nation's data, that they could replicate the conclusions from happiness research on other countries. We ourselves stumbled on this in the 1990s, though we had started such work with data sets only on Britain and the USA.

The second is that it makes little difference whether the well-being measure is happiness or life satisfaction; the four columns of Table 4 illustrate that. In each variant, the qualitative structure of the two kinds of equations is the same.

The third is that it seems possible to assess the happiness levels of different countries in comparable ways. This is achieved by examining regression-equation coefficients for different nations. Doing this, Table 4 paints what in the research literature is now, to researchers, a familiar cross-country pattern (seen by reading off the country-dummy coefficients).

In Table 4, which draws upon data from 2007, the particularly satisfied nations include Denmark (coefficient 1.4820)

Sweden

Finland

Norway

Luxembourg 
The Netherlands

Ireland

and the rather dissatisfied European countries include

Bulgaria (-1.8028)

Hungary

Macedonia

Latvia.

As is clear from this list, and Table 4 more broadly, East European transition nations have citizens who are particularly unhappy with their lives.

What might be viewed as remarkable, and was unpredicted by researchers, is the relatively poor standing -- in a well-being league table -- of certain West European nations such as Italy (-0.3473) and Portugal (-0.4631). Currently it is not known why these nations come out so low.

For some years now, the Human Development Index, or HDI, has been promoted by the United Nations. In a sense, it was an early attempt to go beyond the tradition of viewing GDP as the sufficient statistic for well-being. The HDI index is an amalgamation of three kinds of data: on real income; lifespan; and education. Although conceived independently, the HDI index links intellectually to the newer empirical research on happiness. Figure 1 shows that, across European nations, there is a reasonably close correlation between HDI and subjective wellbeing.

Where does the United States lie in a world ranking of happiness levels? To answer that, it is necessary to have cross-national data on statistically representative samples of the population collected in the same way in every country. Such data sets are now available. One 
source (others are the World Values Survey and recent Gallup Poll data) is the International Social Survey Programme, or ISSP.

In this ISSP case, the well-being question is: "If you were to consider your life in general these days, how happy or unhappy would you say you are, on the whole? [4] Very happy; [3] Fairly happy; [2] Not very happy; [1] Not at all happy.”

Table 5 reports an ISSP international happiness equation, and again codes the dependent variable in a cardinal way. It covers data on 33 nations. In this case, Australia is set as the base country against which coefficient comparisons are made. The 'happiest' countries are

Ireland (coefficient 0.2196)

Switzerland (0.1677)

Mexico (0.1559)

USA (0.0939)

Great Britain (0.0844)

New Zealand (0.0754)

And the least happy are

Russia (-0.6096)

Bulgaria (-0.4958)

Latvia (-0.4257)

Croatia (-0.3718).

Hence the USA does very respectably. Other interesting patterns in Table 5 include the fact that Finland and France come out relatively poorly, on -0.2285 and -0.3285 , respectively. South Korea also appears low down a well-being scale, with a country dummy coefficient of -0.3483 . 
As in the earlier tables, it can be seen in Table 5 that age enters in a U-shaped way (and Figure 2 shows this even in raw European data, without any control variables); disabled and unemployed variables are associated with large negative happiness values; once more, maritalstatus variables are prominent. Being religious is positive in a happiness equation. Having a university degree comes in large and positive (there is no income variable in this ISSP equation). Interestingly, in the full sample in column 1 of Table 5, there is no gender effect on happiness. Separate equations for males and females are also given. They have the same structure, so it might be said, put loosely, that the determinants of happiness for men and for women are almost identical.

Table 6 reports on how happiness has changed over the recent years of recession. It provides three separate regressions plus nations' mean scores. Data are available on life satisfaction in the twenty-seven European Union countries plus Croatia, Iceland (in 2010 only), Macedonia and Turkish Cyprus, in 2007, 2009 and most recently in May 2010. It is apparent that there has been a decline in the happiness levels in Greece and Portugal, measured both by a decline in their mean scores and also in the relative rankings in the happiness regressions. These countries have arguably been especially affected by the sovereign debt crisis and rising bond yields, and their governments have implemented severe fiscal austerity measures. Interestingly, the happiness level of the Irish increased over time, as it did in the UK as well as in Germany and Sweden. It remains to be seen whether happiness levels will remain at such levels in the UK and Ireland (as the countries' recent austerity measures start to bite). ${ }^{5} \mathrm{We}$ also find evidence that

\footnotetext{
${ }^{5}$ Since May 2010 both consumer and business confidence in the UK have fallen sharply plus there is evidence of further house price declines. The December 2010 labour market release by the Office of National Statistics suggested that the unemployment rate has started to rise again. Value-added tax is set to rise in January 2011 from $17.5 \%$ to $20 \%$ with further and tax increases, along with unprecedented cuts in public spending and public sector job losses in 2011.
} 
the well-being of the least educated and the unemployed, relative to the employed, has fallen sharply. The happiness of men relative to women has also fallen in the recession.

What of feelings of well-being in the workplace? Although there has been a long history to the study of data on job satisfaction, comparable estimates across nations are rarer.

Table 7 provides an illustration. It shows the structure of a job satisfaction regression for the United States. Older people, holding other factors constant, are more satisfied (the coefficient in column 1 of Table 6 is 0.0084 , which implies that being 60 rather than 20 is associated with approximately half an extra standard deviation on job satisfaction). There is only a slight difference between males and females: men are less satisfied with their job. An enormous difference is noticeable between self-employed individuals and others. In column 1 of Table 6 , the coefficient is a remarkable 0.2 , which implies that there is a major satisfaction premium from self-employment. Black people are much less satisfied with work than whites or non-whites. Over time, since the beginning of the data in 1972, there is evidence of a slight downward trend in job satisfaction in the United States (coefficient -0.0015). In Table 6, the highly educated are more satisfied; so too are part-timers.

Column 2 of Table 7 makes clear that there is a powerful link between job insecurity and low well-being. Those workers who think it 'not at all likely' they will lose their job are approximately 0.3 satisfaction points more content than those who believe it is fairly likely. Another negative influence (-0.1079) comes from answering: 'it would be not at all easy to find another job'. In column 3 , which adds a variable for being a union member, there is no statistically significant association between the level of job satisfaction and being in a trade union. What does matter, however, as would be anticipated, is the level of a person's income. In column 4 of Table 7, it is clear that when the $\log$ of annual pay is entered as a control its 
effect is strong and positive. Moreover, the level of education then loses statistical significance. It seems that educated Americans are more satisfied with their working life principally because their education brings them a higher annual salary. There is a large literature on job satisfaction and productivity that we cannot here review (Judge et al, 2001).

Table 8 provides data on the level and distribution of Americans' job satisfaction scores through the years. Little change is evident to the eye between 1972 and 2008, even though the earlier regression equation could, after adjusting for people's characteristics, detect a small secular decline.

\section{Interpreting the Patterns}

One intriguing fact comes through strongly in these tables and has been found often in the literature. Whether using regression equations or simple tabulations, small or large samples, simple cross-sections or pooled data, a number of the small social-democratic countries of Europe are consistently estimated to be among the world's happiest nations.

While the multi-country studies' findings are intriguing, commentators like Ostroot and Snyder (1985) and Argyle (2001) point out that it is hard to know what to make of the crossnational claims. First, language differences raise the worry that words like 'life satisfaction' cannot be translated sufficiently consistently to ensure that the variations in reported well-being are meaningful. Second, cultural differences -- in some countries it may be less acceptable to admit to unhappiness -- further complicate inference. Third, when visited, these European nations anecdotally appear similar in wealth, and indeed in most ways of living. None of these objections is definitive; but all of them mean that there are doubts over the substantive interpretation of estimated cross-national happiness variation. 
Some writers have nevertheless made a case for taking cross-country subjective wellbeing data seriously in the evaluation of human welfare. ${ }^{6}$ This form of research may even presage for international agencies a move away from simple GDP targets of the sort that have been favoured in post-war economic policy. However, to make progress on the construction of a national well-being index, a better empirical justification for the use of subjective lifesatisfaction and happiness statistics may be needed.

Blanchflower and Oswald (2008b) try to deal with that concern. Their paper takes an unconventional approach to the assessment of well-being. It explores the use of cross-national survey data on hypertension (that is, high blood-pressure). The paper estimates both psychological well-being and blood-pressure equations. Using Pearson and Spearman rank tests, it finds that the structure of the coefficients on country dummy variables is similar in both kinds of regression equations. Happy countries seem to have fewer blood-pressure problems. This has two implications. First, it suggests that there may be a case to take seriously the subjective 'happiness' measurements made across the world: they follow a pattern that is reassuringly like the (inverse of) high-blood-pressure estimates. Second, in constructing new kinds of economic and social policies in the future, where well-being rather than real income is likely to be a prime concern, there are grounds for economists to study people's blood pressure.

The believability of subjective well-being patterns across nations can be scrutinized in other ways. Various happiness correlates can be studied, for instance, in the search for corroboration. Di Tella et al (2003) show, encouragingly for the quality of subjective data, that in a sample of Western nations there is evidence that the rises and falls in suicide rates move in the opposite direction to changes in happiness. The null hypothesis of no correlation, however,

\footnotetext{
${ }^{6}$ See for example Easterlin (1974), Clark and Oswald (1994), Inglehart (1996), Ng (1997), Oswald (1997), Diener (2000), Kahneman et al (2004), and Vemuri and Constanza (2006).
} 
can be rejected only at the $10 \%$ level. Bray and Gunnell (2006) demonstrate that suicide is negatively correlated with happiness, and can reject the null of a zero correlation at the 5\% level; but in a smaller sample Lester (2002) does not find such clear-cut results. Other national correlates studied in the literature include trust and political institutions (Hudson 2006, Helliwell 2003). None of these articles, though, is an attempt to evaluate the persuasiveness of different measures of mental well-being. There is some evidence that happiness and heart rate are negatively associated among men, and that well-being is correlated with cortisol levels and cardiovascular behaviour (Steptoe et al 2005). However, internationally comparable measures of hypertension, where the demographic and educational characteristics of randomly sampled people are known, are in short supply. Social scientists have paid little attention to the idea that heart variables could play a role as a relevant well-being variable.

In the Blanchflower and Oswald (2008b) Journal of Health Economics study, the data set is a Eurobarometer survey which collected identical survey information in September and October 2001 from approximately 15,000 randomly sampled individuals in Denmark, West Germany, Greece, Italy, Spain, France, Ireland, Luxembourg, the Netherlands, Portugal, the United Kingdom, East Germany, Finland, Sweden, Austria, and Belgium.

Much research has now been done that attempts to explain the cross-country pattern of subjective well-being. Credit should go especially to Ed Diener and colleagues for analysis on this (Diener et al 1995a, b). At the level of correlation, it has been argued that happy countries have:

Low inequality (Alesina et al 2004; Winkelmann and Winkelmann 2010)

High social capital and strong friendship networks (Bjornskov 2003; Vermuri and Constanza 2006; Bjornskov et al 2008) 
Low unemployment and inflation (Di Tella et al 2001, 2003; Helliwell 2003; Gandelman and Hernandez-Murillo 2009; Whiteley et al 2010)

High levels of democracy and democratic participation (Frey and Stutzer 2000; Helliwell and Huang 2008)

High trust (Hudson 2006)

Strong welfare states and public spending (DiTella et al 2003, Pacek and Radcliff 2008; Kotakorpi and Laamen 2010)

Low pollution (DiTella and MacCulloch 2008).

The Bjornskov et al (2008) paper is of particular interest. It examines the statistical impact of a wide range of cross-country determinants of life satisfaction. To do so, it exploits a database of 90,000 observations in 70 countries. The authors distinguish four groups of aggregate variables as potential determinants of satisfaction: political, economic, institutional, and human development and culture. They then use ordered probits to investigate the importance of these variables on individual life satisfaction and test the robustness of the results with Extreme Bounds Analysis. Their results reveal that "only a small number of factors, such as openness, business climate, post-communism, the number of chambers in parliament, Christian majority, and infant mortality" robustly influence life satisfaction across countries while the importance of many variables suggested in the previous literature is not confirmed. This remains largely true, they argue, when the analysis splits national populations according to gender, income, and political orientation also.

Another notable study is DiTella and MacCulloch (2008). The Easterlin Paradox, as explained earlier, refers to the fact that happiness data are typically stationary in spite of considerable increases in income. This amounts, DiTella and MacCulloch argue, to a rejection of 
the hypothesis that current income is the only argument in the utility function. They then show that the happiness responses of around 350,000 people living in the OECD between 1975 and 1997 are positively correlated with the level of the country's income, the welfare state and (weakly) with life expectancy; they are negatively correlated with the average number of hours worked, environmental degradation (measured by SO emissions), crime, openness to trade, inflation and unemployment. This analysis is done with controls for country and year dummies. In an original line of argument, the authors show that effects separate across groups in a pattern that appears plausible (e.g., the rich suffer environmental degradation more than the poor). Based on actual changes from 1975 to 1997 , they show, only small contributions to happiness can be attributed to the increase in income in our sample. In fact, the actual changes in several of the 'omitted variables' such as life expectancy, hours worked, inflation and unemployment also contribute to happiness over this time period since life expectancy has risen and the others have, on average, fallen. Consequently, the DiTella-MacCulloch study concludes that the unexplained trend in happiness is even bigger than would be predicted if income was the only argument in the utility function. In other words, introducing omitted variables further confirm Richard Easterlin's nation income-growth-without-happiness paradox.

\section{The Future and Possible Links with Medical Research}

Other kinds of researchers study human well-being. Our instinct is that this socialscience literature on happiness will slowly join up with a medical and biological literature on physical well-being. Some epidemiological publishing of this kind is already visible; the connections between the mind and the body are known to be important, and well-being research by its nature has to consider both the mental and the physical. ${ }^{7}$

\footnotetext{
7 Work at the border between health and happiness currently includes Jonas and Lando (2000), Cohen et al (2003), Ebrecht et al (2004), Steptoe et al (2005), Bell and Blanchflower (2007), Blanchflower and Oswald (2008b), and
} 
There are at least three reasons why it can be expected that in the future these different literatures and academic disciplines will draw together. One is that the distinction between happiness and mental health is growing ever more blurry (see Hu et al 2007, for example, which shows that mental health scores are measures of positive well-being and thus not just of use to psychiatrists). The second is that the distinction between physical and psychological health is arguably artificial. It is known in the happiness literature that health variables enter in statistically significant ways in well-being equations. The third is that if the health of the body and the health of the mind are connected -- and there is growing evidence of this, including in papers such as Cohen et al (2003), and Ebrecht et al (2004) -- it is scientifically unattractive to try to keep the two strands apart in research.

Nevertheless, it is not easy to believe that the convergence of the happiness, mentalhealth, psychology, and medical literatures will occur quickly (even though it would be scientifically valuable if it did). A central reason is that researchers do not have strong incentives to read and cite beyond their own discipline's journals. Also, although classical statistical theory underpins all work in these fields, different kinds of disciplines have evolved different ways of presenting data and tests. Statistical and linguistic conventions differ from one discipline to another. Compare, for instance, the style of papers in Science, the New England Journal of Medicine, the Quarterly Journal of Economics, and the Journal of Personality and Social Psychology. Few social scientists have had any training in physiology, and few physicians and hard-scientists have been trained in social science. We believe that not many of those who advocate interdisciplinary work have tried to publish in the elite journals of other disciplines than their own; the practical difficulties are intense.

Graham (2008). The biomarker literature includes Edmunds (1982), Steptoe et al (2005), Crimmins et al (2008), Seeman et al (2008), and Singh and Rose (2009). 
All this means that the language, sociological, and stylistic differences across academic disciplines act as a set of barriers that will slow the rate of intellectual convergence. Nevertheless, the study of human well-being is intrinsically as multi-disciplinary as it is fascinating. In our opinion, this is an arena in which the hard sciences and the social sciences inherently abut one another. Slowly, perhaps painfully, we will all have to learn to talk to one another.

\section{Conclusions}

Human well-being is of intellectual and personal interest to individuals, social scientists, and policy-makers. Understanding the determinants of something as complex as happiness is difficult; attempts to do so will, inevitably, continue to provoke disagreement. However, in the last few decades, and especially through the 2000s, a new literature -- for which researchers like the economist Richard Easterlin and the psychologists Edward Diener and (the late) Michael Argyle take particularly early credit -- has sprung up. In it, scholars use data on subjective wellbeing to explore the statistical determinants of happiness, life satisfaction, and mental health.

Much of the considerable knowledge that has been gained is currently at the level of correlation. That does not make it wrong or misleading. But it does mean that, as is often true with observational -- rather than experimental -- social science, we have to be cautious before we can go from even very strong patterns in the data to judgments about cause-and-effect (in a form, say, that would be decisively helpful to those involved in policy-making). The very latest style of statistical research, which is seen in scholarly journals more and more frequently, draws on longitudinal well-being data, and on experimental or quasi-experimental methods. This work should gradually, in the way common in modern social-science, lead to a better causal understanding. 
Currently, the main patterns -- as illustrated earlier in our tables -- that have been replicated persuasively in the data of large numbers of nations are the following. Happy people are disproportionately the young and old (not middle-aged), rich, educated, married, in work, healthy, exercise-takers, with high fruit-and-vegetable diets, and slim. Recent work on BMI and well-being includes Oswald and Powdthavee (2007) and Blanchflower et al (2009). Happy countries are disproportionately rich, educated, democratic, trusting, and low-unemployment.

Even bearing in mind the latter characteristics, some nations do noticeably well in happiness rankings. Examples include Denmark, the Netherlands and Ireland. Unfortunately, we do not yet know why these countries are so perplexingly happy (Biswas-Diener et al 2010 think that part of Denmark's secret is that it somehow cuts down on the statistical tail, that is, has low numbers of extremely unhappy individuals). It is difficult to avoid noticing that smallness of a country seems in the data somehow to help it be a happy one. That may be a spurious correlation, or may indicate perhaps that a geographical or low-population country feels genuinely more like a single, friendly unit (one of us recently heard a Danish politician explain Denmark's high happiness by saying 'we feel we are all one tribe'). It is likely that many other characteristics of nations matter, at a deep level, for human happiness; our knowledge here is sparse. Nor do we yet understand how the physical health and mental health of nations are connected. That fascinating research area lies almost uncharted. It will surely provide material for hundreds of future PhDs.

By its nature, this multi-disciplinary research field is, and will remain, one of genuine significance to human society. Almost everyone is interested in happiness. 


\section{References}

Alesina, A., Di Tella, R., \& MacCulloch, R. (2004). Inequality and happiness: Are Americans and Europeans Different? Journal of Public Economics, 88, 1009-2042

Appleton, S., \& Song, L. (2008). Life satisfaction in urban China: Components and determinants. World Development, 36, 2325-2340.

Argyle, M. (2001). The psychology of happiness. London: Routledge, Second edition.

Bell, D., \& Blanchflower, D.G. (2007). The Scots may be brave but they are neither healthy nor happy. Scottish Journal of Political Economy, 54, 166-194.

Bell, D., \& Blanchflower, D.G. (2010). UK unemployment in the great recession, National Institute Economic Review, London, October 214, R3-R25.

Biswas-Diener, R., Vitterso, J., \& Diener, E. (2010). The Danish effect: Beginning to explain high well-being in Denmark. Social Indicators Research, 97, 229-246.

Bjornskov, C. (2003). The happy few: Cross-country evidence on social capital and life satisfaction. Kyklos, 56, 3-16.

Bjornskov, C., Dreher, A., \& Fischer, J.A.V. (2008). Cross-country determinants of life satisfaction: Exploring different determinants across groups in society. Social Choice and Welfare, 30, 119-173.

Blanchflower, D.G. (2001). Unemployment, well-being and wage curves in Eastern and Central Europe. Journal of Japanese and International Economies, 15, 364-402.

Blanchflower, D.G. (2009). International evidence on well-being. In Measuring the Subjective Well-being of Nations, edited by Alan Krueger, NBER and University of Chicago Press.

Blanchflower, D.G. (2011). The well-being of the young, Dartmouth College Working Paper.

Blanchflower, D.G., \& Oswald, A.J. (2004). Well-being over time in Britain and the USA. Journal of Public Economics, 88, 1359-1386.

Blanchflower, D.G., \& Oswald, A.J. (2008a). Is well-being U-shaped over the life cycle? Social Science \& Medicine, 66, 1733-1749.

Blanchflower, D.G., \& Oswald, A.J. (2008b). Hypertension and happiness across nations. Journal of Health Economics, 27, 218-233.

Blanchflower, D.G., Oswald, A.J., \& Van Landeghem, B. (2009). Imitative obesity and relative utility. Journal of the European Economic Association, 7, 528-538.

Bray, I., \& Gunnell, D. (2006). Suicide rates, life satisfaction and happiness as markers for population mental health. Social Psychiatry and Psychiatric Epidemiology, 41, 333-337.

Brown, G.D.A, Gardner, J., Oswald, A.J., \& Qian, J. (2008). Does wage rank affect employees' well-being? Industrial Relations, 47, 355-389.

Christensen, K., Herskind, A.M., \& Vaupel, J.W. (2006). Why Danes are so smug: Comparative study of life satisfaction in the European Union. BMJ: British Medical Journal, 333, 12891291.

Clark, A.E., \& Oswald, A.J. (1994). Unhappiness and unemployment. Economic Journal, 104, 648-659.

Clark, A.E., Frijters, P., \& Shields, M.A. (2008). Relative income, happiness, and utility: An explanation for the Easterlin paradox and other puzzles. Journal of Economic Literature, 46, 95-144.

Clark, A.E., \& Senik, C. (2010). Who compares to whom? The anatomy of income comparisons in Europe. Economic Journal, 120, 573-594.

Cohen, S., Doyle, W.J., Turner, R.B., Alper, C.M., \& Skoner, D.P. (2003). Emotional style and susceptibility to the common cold. Psychosomatic Medicine, 65, 652-657 
Crimmins, E., Vasunilashorn, S., Kim, J.K., \& Alley, D. (2008). Biomarkers related to aging in human populations. Advances in Clinical Chemistry, 46, 161-216.

Daly, M.C., \& Wilson, D.J. (2009). Happiness, unhappiness, and suicide: An empirical assessment. Journal of the European Economic Association, 7, 539-49.

Daly, M., Oswald, A.J., Wilson, D., \& Wu, S. (2010). Dark contrasts. Working paper, Warwick University.

Deaton, A. (2008). Income, health, and well-being around the world: Evidence from the Gallup World Poll. Journal of Economic Perspectives, 22, 53-72.

Devoe, S.E., \& Pfeffer, J. (2009). When is happiness about how much you earn? The effect of hourly payment on the money-happiness connection. Personality and Social Psychology Bulletin, 35, 1602-18.

Diener, E., Suh, E.M., Smith, H., \& Shao, L. (1995a). National differences in reported subjective well-being - Why do they occur? Social Indicators Research, 34, 7-32.

Diener, E., Diener, M., \& Diener, C. (1995b). Factors predicting the subjective well-being of nations. Journal of Personality and Social Psychology, 69, 851-864.

Diener, E., Ng, W., Harter, J. et al. (2010). Wealth and happiness across the world: Material prosperity predicts life evaluation, whereas psychosocial prosperity predicts positive feeling. Journal of Personality and Social Psychology, 99, 52-61.

Diener, E., Lucas, R.E., \& Schimmack, U. (2008). National accounts of well-being. Oxford, UK: Oxford University Press.

Di Tella, R., MacCulloch, R.J., \& Oswald, A.J. (2001). Preferences over inflation and unemployment: Evidence from surveys of happiness. American Economic Review, 91, 335341.

Di Tella, R., MacCulloch, R.J., \& Oswald, A.J. (2003). The macroeconomics of happiness. Review of Economics and Statistics, 85, 809-827.

Di Tella, R., \& MacCulloch, R.J. (2008). Gross national happiness as an answer to the Easterlin Paradox? Journal of Development Economics, 86, 22-42.

Dolan, P., Peasgood, T., \& White, M. (2008). Do we really know what makes us happy? A review of the economic literature on the factors associated with subjective well-being. Journal of Economic Psychology, 29, 94-122.

Duesenberry, J.S. (1949). Income, Saving and the Theory of Consumer Behavior. Cambridge, MA: Harvard University Press.

Easterlin, R.A. (1974). Does economic growth improve the human lot? Some empirical evidence. In: David PA, Reder MW (Eds.), Nations and households in economic growth: Essays in honor of Moses Abramowitz. New York: Academic Press; p. 89-125.

Easterlin, R.A. (2003). Explaining happiness. Proceedings of the National Academy of Sciences of the USA, 100, 11176-11183.

Ebrecht, M., Hextall, J., Kirtley, L.G., Taylor, A., Dyson, M., \& Weinman, J. (2004). Perceived stress and cortisol levels predict the speed of wound healing in healthy male adults. Psychoneuroendocrinology, 29, 798-809.

Edmunds, O.P. (1982). The heart rate of students in examinations. Journal of Social and Occupational Medicine, 32, 32-36.

Fahey, T., \& Smyth, E. (2004). Do subjective indicators measure welfare? Evidence from 33 European societies. European Societies, 6, 5-27. 
Fliessbach, K., Weber, B., Trautner, P., Dohmen, T., Sunde, U., Elger, C., \& Falk, A. (2007). Social comparison affects reward-related brain activity in the human ventral striatum. Science, 318, 1305-1308.

Frey, B.S., \& Stutzer, A. (2000). Happiness, economy and institutions. Economic Journal, 110, 918-938.

Frey, B.S., \& Stutzer, A. (2002). Happiness and economics. Princeton: Princeton University Press.

Gandelman, N., \& Hernandez-Murillo, R. (2009). The impact of inflation and unemployment on subjective personal and country evaluations. Federal Reserve Bank of St Louis Review, 91, 107-126.

Gilbert, D. (2006). Stumbling on happiness. New York: Alfred A Knopf.

Goldberg, D.P., Gater, T., Sartorious, N., Ustun, T.B., Piccinelli, M., Gureje, O., \& Rutter, C. (1997). The validity of two versions of the GHQ in the WHO study of mental illness in general health care. Psychological Medicine, 27, 191-197.

Graham, C. (2005). Insights on development from the economics of happiness. World Bank Research Observer, 20, 201-231.

Graham, C. (2008). Happiness and health: Lessons - and questions - for public policy. Health Affairs, 27, 72-87.

Graham, C. (2009). Happiness around the world: The paradox of happy peasants and miserable millionaires. Oxford: Oxford University Press.

Grant, A.M., Christianson, M.K., \& Price, R.H. (2007). Happiness, health, or relationships? Managerial practices and employee well-being tradeoffs. Academy of Management Perspectives, 21, 51-63.

Green, F. (2006). Demanding work: The paradox of job quality in the affluent economy. Princeton: Princeton University Press.

Green, F., \& Tsitsianis, N. (2005). An investigation of national trends in job satisfaction in Britain and Germany. British Journal of Industrial Relations, 43, 401-429.

Hagerty, M.R. (2000). Social comparisons of income in one's community: Evidence from national surveys of income and happiness. Journal of Personality and Social Psychology, 78, 764-771.

Hagerty, M.R., \& Veenhoven, R. (2003). Wealth and happiness revisited: Growing national income does go with greater happiness. Social Indicators Research, 64, 1-27.

Helliwell, J. (2003). How's life? Combining individual and national variables to explain subjective well-being. Economic Modelling, 20, 331-360.

Helliwell, J., \& Huang, H.F. (2008). How's your government? International evidence linking good government and well-being. British Journal of Political Science, 38, 595-619.

Hodiamont, P.P.G., Rijnders, C.A.T., Mulder, J. \& Furer, J.W. (2005). Psychiatric disorders in a Dutch Health Area: A repeated cross-sectional survey. Journal of Affective Disorders, 84, 77-83.

Howell, R.T., \& Howell, C.J. (2008). The relation of economic status to subjective well-being in developing countries: A meta-analysis. Psychological Bulletin, 134, 536-560.

Hu, Y.J., Stewart-Brown, S., Twigg, L., \& Weich, S. (2007). Can the 12-item General Health Questionnaire be used to measure positive mental health? Psychological Medicine, 37, 1005-1013.

Hudson, J. (2006). Institutional trust and subjective well-being across the EU. Kyklos, 59, 43-62. 
Huppert, F., \& Whittington, J.E. (2003). Evidence for the independence of positive and negative well-being: Implications for quality of life assessment. British Journal of Health Psychology, 8, 107-122.

Inglehart, R. (1996). The diminishing utility of economic growth: From maximizing security toward maximizing subjective well-being. Critical Review, 10, 509-531.

Jonas, B.S., \& Lando, J.F. (2000). Negative affect as a prospective risk factor for hypertension. Psychosomatic Medicine, 62, 188-196.

Judge, T.A., Locke, E.A., Durham, C.C. et al. (1998). Dispositional effects on job and life satisfaction: The role of core evaluations. Journal of Applied Psychology, 83, 17-34.

Judge, T. A., Thoresen, C. J., Bono, J. E., \& Patton, G. K. (2001). The job satisfaction-job performance relationship: A qualitative and quantitative review. Psychological Bulletin, 127, 376-407.

Judge, T.A., Ilies, R., \& Dimotakis, N. (2010). Are health and happiness the product of wisdom? The relationship of general mental ability to educational occupational attainment, health, and well-being. Journal of Applied Psychology, 95, 454-468.

Kahneman, D., \& Deaton, A. (2010). High income improves evaluation of life but not emotional well-being. Proceedings of the National Academy of Sciences of the USA, 107, 1648916493.

Kahneman, D., Krueger, A.B., Schkade, D., Schwarz, N., \& Stone, A. (2004). Toward national well-being accounts. American Economic Review, 94, 429-434.

Kotakorpi, K., \& Laamen, J.P. (2010). Welfare state and life satisfaction: Evidence from Public Health Care. Economica, 77, 565-583.

Krueger, A.B. \& Schkade, D.A. (2008). The reliability of subjective well-being measures. Journal of Public Economics, 92, 1833-1845.

Layard, R. (2010). Measuring subjective well-being. Science, 327, 534-535.

Luechinger, S. (2009). Valuing air quality using the life satisfaction approach. Economic Journal, 119, 482-515.

Lester, D. (2002). National ratings of happiness, suicide, and homicide. Psychological Reports, 91, 758-758.

Luttmer, E. (2005). Neighbors as negatives: Relative earnings and well-being. Quarterly Journal of Economics, 120,963-1002.

Napier, J.L., \& Jost, J.T. (2008). Why are conservatives happier than liberals? Psychological Science, 19, 565-572.

Ng, Y.K. (1997). A case for happiness, cardinalism, and interpersonal comparability. Economic Journal, 107, 1848-1858.

Offer, A. (2006). The challenge of affluence: Self-control and well-being in the United States and Britain since 1950. Oxford: Oxford University Press.

Ostroot, N.M., \& Snyder, W.W. (1985). Measuring cultural bias in a cross-cultural study. Social Indicators Research, 17, 243-251.

Oswald, A.J. (1997). Happiness and economic performance. Economic Journal, 107, 1815-1831.

Oswald, A.J. (2010). Emotional prosperity and the Stiglitz Commission. British Journal of Industrial Relations, 48, 651-669.

Oswald, A.J., \& Powdthavee, N. (2007). Obesity, unhappiness, and the challenge of affluence: Theory and evidence. Economic Journal, 117, F441-454.

Oswald, A.J., \& Wu, S. (2010). Objective confirmation of subjective measures of human wellbeing: Evidence from the USA. Science, 327, 576-579. 
Oswald, A.J. \& Wu, S. (2011). Well-being across America. Review of Economics and Statistics, forthcoming.

Pacek, A.C., \& Radcliff, B. (2008). Welfare policy and subjective well-being across nations: An individual-level assessment. Social Indicators Research, 89, 179-191.

Pfeffer, J. (2010). Building sustainable organizations: The human factor. Academy of Management Perspectives, 24, 34-45.

Pittau, M.G., Zelli, R., \& Gelman, A. (2010). Economic disparities and life satisfaction in European regions. Social Indicators Research, 96, 339-361

Powdthavee, N. (2005). Unhappiness and crime: Evidence from South Africa. Economica, 72 , 531-547.

Powdthavee, N. (2008). Putting a price tag on friends, relatives, and neighbours: Using surveys of life-satisfaction to value social relationships. Journal of Socio-Economics, 37, 14591480 .

Powdthavee, N. (2010). The happiness equation. Duxford: Icon Books.

Radcliff, B. (2001). Politics, markets, and life satisfaction: The political economy of human happiness. American Political Science Review, 95, 939-952.

Rehdanz, K., \& Maddison, D. (2008). Local environmental quality and life-satisfaction in Germany. Ecological Economics, 64, 787-797.

Schyns, P. (2002). Wealth of nations, individual income and life satisfaction in 42 countries: A multilevel approach. Social Indicators Research, 60; 5-40.

Sacker, A., \& Wiggins, R.D. (2002). Age-period-cohort effects on inequalities in psychological distress, 1981-2000. Psychological Medicine, 32, 977-990.

Seeman, T., Merkin, S.S., Crimmins, E., Koretz, B., Charette, S., \& Karlamangla, A. (2008). Education, income, and ethnic differences in cumulative biological risk profiles in a national sample of US adults: NHANES III 1988-1994. Social Science \& Medicine, 66, 7287.

Singh, I., \& Rose, N. (2009). Biomarkers in psychiatry. Nature, 460, 202-207.

Stack, S., \& Eshelman, J.R. (1998). Marital status and happiness: A 17-nation study. Journal of Marriage and the Family, 60, 527-536.

Steptoe, A., Wardle, J., \& Marmot, M. (2005). Positive affect and health-related neuroendocrine, cardiovascular, and inflammatory processes. Proceedings of the National Academy of Science of the United States of America, 102, 6508-6512.

Steel, P, \& Ones, D.S. (2002). Personality and happiness: A national-level analysis. Journal of Personality and Social Psychology, 83, 767-781.

Stevenson, B., \& Wolfers, J. (2008). Economic growth and subjective well-being: Reassessing the Easterlin Paradox. Brookings Papers on Economic Activity, Spring, 1-102.

Stone, A.A., Schwartz, J.E., Broderick J.E., et al. (2010). A snapshot of the age distribution of psychological well-being in the United States. Proceedings of the National Academy of Sciences of the USA, 107, 9985-9990.

Van Praag, B., \& Ferrer-I-Carbonell, A. (2004). Happiness quantified: A satisfaction calculus approach. Oxford University Press: Oxford.

Veenhoven, R. (1999). Quality-of-life in individualistic society. Social Indicators Research, 48, 157-186.

Vemuri, A.W., \& Constanza, R. (2006). The role of human, social, built, and natural capital in explaining life satisfaction at the country level: Toward a National Well-being Index (NWI). Ecological Economics, 58, 119-133. 
Welsch, H. (2006). Environment and happiness: Valuation of air pollution using life satisfaction data. Ecological Economics, 58, 801-813.

Whiteley, P., Clarke, H.D., Sanders, D., \& Stewart, M.C. (2010). Government performance and life satisfaction in contemporary Britain. Journal of Politics, 72, 733-746.

Winkelmann, L., \& Winkelmann, R. (2010). Does inequality harm the middle class? Kyklos, 63, 301-316.

Wolfers, J. (2003). Is business cycle volatility costly? Evidence from surveys of well-being. International Finance, 6, 1-26. 
Table 1. Happiness Equations for the United States, 1972-2008

(1)

Age
Age $^{2}$
Male
Black
Other non-white
Time trend
\#Years of schooling
Work part-time
Temp not working
Unemployed
Retired
School
Home worker
Married
Widowed
Divorced
Separated
Parents divorced @16
Annual income
Constant

Adjusted $\mathrm{R}^{2}$
$-.0053(5.57)$

$.00007(7.67)$

$-.0497(7.91)$

$-.1312(15.43)$

$-.0456(3.19)$

$-.0002(0.84)$

$.0170(17.66)$

$-.0282(2.89)$

$-.0775(3.99)$

$-.2343(14.10)$

$-.0043(0.39)$

$.0335(1.96)$

$-.0384(4.28)$

$.2322(27.51)$

$-.0924(6.94)$

$-.0750(6.73)$

$-.1430(8.62)$

$-.0436(4.97)$

2.0228

.0820

48,189
(2)

$-.0135(8.60)$

$.00016(9.51)$

$-.0620(8.08)$

$-.1362(12.45)$

$-.0400(2.35)$

$-.0017(4.02)$

$.0126(9.36)$

$-.0051(0.45)$

$-.0584(2.79)$

$-.2164(11.05)$

$.0548(1.96)$

$.1223(4.29)$

$-.0179(0.92)$

$.2227(22.30)$

$-.1017(4.76)$

$-.0563(4.29)$

$-.1035(5.04)$

$-.0353(3.37)$

.00246 (9.72)

2.2125

.0783

28,107

These are two happiness regressions -- each is to be read vertically -- in which the dependent variable is people's answer to the question: Taken all together, how would you say things are these days -- would you say that you are very happy, pretty happy, or not too happy? Answers are coded cardinally from 3 down to 1.

Base categories (relative to which coefficients are measured): white, single, and working full-time. T-statistics in parentheses.

Here, and in later tables, t-statistics are in parentheses.

Mean(SD) of dependent variable $=2.195(0.635)$

The annual income coefficient has here been scaled up by a factor of 1000 .

Source: General Social Surveys (GSS) 
Table 2. Happiness Through Time in the USA, 1972-2008

Question: 'taken all together, how would you say things are these days-would you say that you are very happy, pretty happy, or not too happy?'

All

Very happy

Pretty happy

Not too happy

$\mathrm{N}$

All

Very happy

Pretty happy

Not too happy

$\mathrm{N}$

All

Very happy

Pretty happy

Not too happy

$\mathrm{N}$

Source: General Social Surveys

19721973197419751976197719781980198219831984

$\begin{array}{rrrrrrrrrrr}30 & 36 & 38 & 33 & 34 & 35 & 34 & 34 & 31 & 31 & 35 \\ 53 & 51 & 49 & 54 & 53 & 53 & 56 & 53 & 55 & 56 & 52 \\ 17 & 13 & 13 & 13 & 13 & 12 & 10 & 13 & 15 & 13 & 13 \\ 1,606 & 1,500 & 1,480 & 1,485 & 1,499 & 1,527 & 1,517 & 1,462 & 1,855 & 1,573 & 1,445\end{array}$

\section{8}

$\begin{array}{rrrrrrrrrrr}29 & 32 & 29 & 34 & 33 & 33 & 31 & 32 & 29 & 30 & 32 \\ 60 & 56 & 57 & 57 & 58 & 58 & 58 & 57 & 59 & 58 & 56 \\ 11 & 11 & 13 & 9 & 10 & 9 & 11 & 11 & 12 & 12 & 12 \\ 1,530 & 1,449 & 1,780 & 1,466 & 1,526 & 1,361 & 1,504 & 1,601 & 2,977 & 2,885 & 2,806 \\ & & & & & & & & & \\ \mathbf{2 0 0 0} & \mathbf{2 0 0 2} \mathbf{2 0 0 4} \mathbf{2 0 0 6} \mathbf{2 0 0 8} & & \text { All } & & & & \\ 32 & 30 & 31 & 31 & 30 & 32 & & & & \\ 58 & 57 & 55 & 56 & 55 & 56 & & & & \\ 11 & 12 & 13 & 13 & 16 & 12 & & & & \end{array}$


Table 3. Well-being Equations for the United States - BRFSS, 2009

\begin{tabular}{|c|c|c|c|c|}
\hline \multirow[b]{2}{*}{ Age } & \multicolumn{2}{|c|}{ Life satisfaction } & \multicolumn{2}{|c|}{ Days of bad mental health } \\
\hline & $-.0039(9.82)$ & $-.0061(15.22)$ & $.0299(6.06)$ & $.0431(8.71)$ \\
\hline $\mathrm{Age}^{2}$ & $.00005(13.03)$ & $.00007(19.39)$ & $-.0007(17.59)$ & $-.0009(20.60)$ \\
\hline Male & $-.0067(3.10)$ & $-.0194(8.99)$ & $-1.1054(42.03)$ & $-1.0160(38.57)$ \\
\hline \#adults in household & $.0013(0.92)$ & $-.0036(2.45)$ & $-.0053(0.29)$ & $.0381(2.09)$ \\
\hline Exercise past 30 days & $.1291(54.23)$ & $.1165(49.13)$ & $-1.3622(46.99)$ & $-1.2729(43.91)$ \\
\hline Black & $.0175(4.46)$ & $.0400(10.20)$ & $-.6370(13.31)$ & $-.8254(17.24)$ \\
\hline Asian & $-.0709(8.93)$ & $-.0571(7.24)$ & $-.6266(6.50)$ & $-.7397(7.69)$ \\
\hline Hawaiian & $.0193(1.26)$ & $.0299(1.97)$ & $-.0142(0.08)$ & $-.1151(0.62)$ \\
\hline American Indian & $-.0022(0.29)$ & $.0248(3.23)$ & $.4234(4.51)$ & $.1840(1.96)$ \\
\hline Other race & $-.0162(2.35)$ & $.0157(2.30)$ & $-.1631(1.95)$ & $-.3890(4.65)$ \\
\hline No race & $-.0848(3.68)$ & $-.0647(2.83)$ & $.9207(3.28)$ & $.7535(2.70)$ \\
\hline Multi-race & $-.0180(0.16)$ & $-.0547(0.50)$ & $1.7733(1.31)$ & $2.0666(1.53)$ \\
\hline Hispanic & $.0054(0.97)$ & $.0369(6.57)$ & $-.1275(1.86)$ & $-.3612(5.27)$ \\
\hline Divorced & $-.0019(0.45)$ & $-.0024(0.58)$ & $.7108(10.81)$ & $.7041(13.60)$ \\
\hline Married & $.2220(60.04)$ & $.1646(43.77)$ & $-.4860(4.35)$ & $-.0573(1.25)$ \\
\hline Widowed & $.0385(8.18)$ & $.0221(4.74)$ & $.2491(27.26)$ & $.3461(6.04)$ \\
\hline Separated & $-.0903(11.73)$ & $-.0879(11.49)$ & $2.5506(5.65)$ & $2.4812(26.59)$ \\
\hline Living as married & $.0759(10.37)$ & $.0532(7.31)$ & $.5027(0.99)$ & $.6694(7.54)$ \\
\hline \#children in household & $-.0026(2.33)$ & $-.0016(1.47)$ & $.0229(4.63)$ & $.0085(0.61)$ \\
\hline Self-employed & $.0047(1.28)$ & $.0166(4.52)$ & $.2084(4.63)$ & $.1044(2.32)$ \\
\hline Unemployed $<12 \mathrm{mths}$ & $-.3056(46.01)$ & $-.2327(34.70)$ & $3.5361(43.78)$ & $2.8813(35.20)$ \\
\hline Unemployed $\geq 12 \mathrm{mths}$ & $-.2431(43.86)$ & $-.1870(33.60)$ & $2.5809(38.35)$ & $2.1283(31.35)$ \\
\hline Home worker & $-.0086(2.07)$ & $.0141(3.40)$ & $.6465(12.74)$ & $.4683(9.21)$ \\
\hline Student & $-.0007(0.08)$ & .0260( & $.7134(7.03)$ & $.4714(4.65)$ \\
\hline Retired & $.0035(1.08)$ & $.0372(11.38)$ & $.6546(16.49)$ & $.4197(10.48)$ \\
\hline Unable to work & $-.3740(85.49)$ & $-.2996(66.05)$ & $7.0322(131.88)$ & $6.3257(113.95)$ \\
\hline BMI & $-.0044(26.33)$ & $-.0039(23.17)$ & $.0451(21.71)$ & $.0412(19.89)$ \\
\hline Fruit \& veg 1-3/day & $.0979(19.43)$ & .0905 (18.09) & $-1.0454(17.04)$ & $-.9771(15.97)$ \\
\hline Fruit \& veg 3-5/day & $.1487(29.22)$ & $.1377(27.23)$ & $-1.3382(21.61)$ & $-1.2450(20.15)$ \\
\hline Fruit \& veg $\geq 5 /$ day & $.1830(34.75)$ & $.1716(32.78)$ & $-1.3990(21.82)$ & $-1.3068(20.43)$ \\
\hline Moderate exercise mins. & $.0000(11.57)$ & $.00003(13.96)$ & $.0001(4.24)$ & $.00009(1.48)$ \\
\hline Vigorous exercise mins. & $.0000(12.94)$ & $.00005(11.93)$ & $-.0000(1.12)$ & $-.00003(3.11)$ \\
\hline Grades $1-8$ & $-.0230(0.75)$ & $-.0156(0.52)$ & $.4528(1.21)$ & $.3804(1.02)$ \\
\hline Grades 9-12 & $-.0025(0.08)$ & $-.0028(0.09)$ & $.4553(1.23)$ & $.4924(1.33)$ \\
\hline HS graduate & $.0246(0.82)$ & $.0025(0.09)$ & $-.0656(0.18)$ & $.2070(0.56)$ \\
\hline Some college & $.0348(1.16)$ & $-.0091(0.31)$ & $.1082(0.29)$ & $.5472(1.49)$ \\
\hline College graduate & $.1034(3.43)$ & $.0221(0.74)$ & $-.3858(1.04)$ & $.2775(0.75)$ \\
\hline Smoked 100 cigarettes & $-.0623(30.37)$ & $-.0577(28.31)$ & $.9483(37.99)$ & $.9191(36.89)$ \\
\hline$\$ 10 \mathrm{k} \&<\$ 15 \mathrm{k}$ income & & $.0334(5.28)$ & & $-.7093(9.17)$ \\
\hline$\$ 15 \mathrm{k} \&<\$ 20 \mathrm{k}$ income & & $.0755(12.54)$ & & $-1.1376(15.44)$ \\
\hline$\$ 20 \mathrm{k} \&<\$ 25 \mathrm{k}$ income & & $.0883(15.02)$ & & $-1.5084(20.96)$ \\
\hline$\$ 25 \mathrm{k} \&<\$ 35 \mathrm{k}$ income & & $.1193(20.68)$ & & $-1.9109(27.08)$ \\
\hline$\$ 35 \mathrm{k} \&<\$ 50 \mathrm{k}$ income & & $.1703(29.75)$ & & $-2.1715(31.01)$ \\
\hline
\end{tabular}


$\$ 50 \mathrm{k} \&<\$ 75 \mathrm{k}$ income $\$ 75 \mathrm{k}$ or more income

Constant

$\mathrm{N}$

Adjusted $\mathrm{R}^{2}$
$.2240(38.44)$

$.3044(52.20)$

3.2513

365,449

.1245
3.1876

365,446

.1368
4.7877

365,307

.1184
$-2.4656(34.59)$

$-2.7976(39.21)$

5.9582

365,303

.1237

The data are from the Behavioral Response Factor Surveillance System (BRFSS). The base categories are: Income $<\$ 10,000$, white; Alabama; single; employees; never attended school; and fruit and vegetables less than once a day or never. Additional controls include if a variable was missing. Equations include 50 state dummies plus dummies for Guam, Puerto Rico, and the US Virgin Islands. T-statistics in parentheses.

Question wordings:

"In general, how satisfied are you with your life?" Here people are able to answer one of the following: Very Satisfied, Satisfied, Dissatisfied, or Very Dissatisfied.

"Thinking about your mental health, which includes stress, depression, and problems with emotions, for how many days during the past 30 days was your mental health not good?"

Mean(SD) life satisfaction=3.37(0.63). Mean number of days of bad mental health=3.35(7.68) 
Table 4. Well-being Equations from the European Quality of Life Survey, 2007 (OLS)

\begin{tabular}{|c|c|c|c|c|}
\hline \multirow[b]{2}{*}{ Age } & \multicolumn{2}{|c|}{ Life satisfaction } & \multicolumn{2}{|c|}{ Happiness } \\
\hline & $-.0589(14.39)$ & $-.0557(11.36)$ & $-.0573(15.39)$ & $-.0577(12.90)$ \\
\hline $\mathrm{Age}^{2}$ & $.0006(15.83)$ & $.0006(12.55)$ & .0005 (14.99) & $.0005(12.37)$ \\
\hline Male & $-.0545(2.42)$ & $-.0319(1.18)$ & $-.0540(2.63)$ & $-.0474(1.93)$ \\
\hline Belgium & $.7099(8.27)$ & $.6395(5.89)$ & $.6004(7.70)$ & $.5344(5.40)$ \\
\hline Bulgaria & $-1.8028(21.09)$ & $-1.9085(17.54)$ & $-1.4252(18.22)$ & $-1.5424(15.49)$ \\
\hline Cyprus & $.2954(3.33)$ & $.2554(2.30)$ & $.3577(4.44)$ & $.3628(3.59)$ \\
\hline Czech Republic & $-.3147(3.84)$ & $-.3997(3.73)$ & $.2468(3.31)$ & $.2128(2.18)$ \\
\hline Denmark & $1.4820(17.32)$ & 1.3749 (12.97) & $1.0359(13.30)$ & $.9400(9.72)$ \\
\hline Estonia & $-.1170(1.35)$ & $-.1613(1.51)$ & $.1413(1.79)$ & $.0958(0.98)$ \\
\hline Finland & $1.1739(13.65)$ & $1.0897(10.21)$ & $.9718(12.43)$ & $.9345(9.61)$ \\
\hline France & $.4054(5.15)$ & $.3495(3.50)$ & $.5210(7.28)$ & $.4542(4.99)$ \\
\hline Germany & $.2508(3.40)$ & $.1420(1.49)$ & $.2187(3.26)$ & $.1398(1.60)$ \\
\hline UK & $.4169(5.28)$ & $.2826(2.65)$ & $.5878(8.19)$ & $.4686(4.83)$ \\
\hline Greece & $-.1739(2.02)$ & $-.2787(2.55)$ & $.1456(1.86)$ & $.0653(0.65)$ \\
\hline Hungary & $-1.0980(12.78)$ & $-1.1889(10.95)$ & $-.1710(2.19)$ & $-.2395(2.42)$ \\
\hline Ireland & $.7444(8.58)$ & $.6805(5.61)$ & $.7518(9.53)$ & $.6254(5.65)$ \\
\hline Italy & $-.3473(4.41)$ & $-.3456(2.88)$ & $-.2819(3.94)$ & $-.3530(3.23)$ \\
\hline Latvia & $-.6727(7.73)$ & $-.6497(5.89)$ & $-.2829(3.57)$ & $-.2334(2.32)$ \\
\hline Lithuania & $-.4941(5.69)$ & $-.5083(4.81)$ & $-.0520(0.66)$ & $-.0394(0.41)$ \\
\hline Luxembourg & $1.1124(12.66)$ & $1.0056(8.53)$ & $.8508(0.65)$ & $.7698(7.16)$ \\
\hline Malta & $.5359(5.97)$ & $.5590(4.76)$ & $.5227(6.40)$ & $.6240(5.82)$ \\
\hline Netherlands & $.8170(9.44)$ & $.7385(6.88)$ & $.6288(8.00)$ & $.5546(5.67)$ \\
\hline Poland & $-.0732(0.92)$ & $-.0696(0.68)$ & $.0318(0.44)$ & $.0611(0.65)$ \\
\hline Romania & $-.3379(3.88)$ & $-.4136(3.79)$ & $-.2384(3.05)$ & $-.2712(2.76)$ \\
\hline Slovakia & $-.3316(3.95)$ & $-.4122(3.80)$ & $.1165(1.53)$ & $.0453(0.46)$ \\
\hline Slovenia & $.2257(2.65)$ & $.1454(1.33)$ & $.2674(3.45)$ & .1867 (1.87) \\
\hline Spain & $.5567(6.45)$ & $.4070(3.41)$ & .4777 (6.09) & $.4484(4.12)$ \\
\hline Sweden & $1.3150(15.25)$ & $1.2612(12.14)$ & $.8281(10.56)$ & $.7919(8.36)$ \\
\hline Turkey & $-.4439(5.49)$ & $-.4684(4.57)$ & $-.5832(7.94)$ & $-.5746(6.15)$ \\
\hline Portugal & $-.4631(5.34)$ & $-.6117(4.88)$ & $-.1894(2.41)$ & $-.2437(2.13)$ \\
\hline Croatia & $-.4187(4.88)$ & $-.4564(4.33)$ & $-.2716(3.47)$ & $-.2597(2.70)$ \\
\hline Norway & $1.1527(13.31)$ & $1.0238(9.66)$ & $.6773(8.60)$ & $.6272(6.49)$ \\
\hline Macedonia & $-1.2987(14.91)$ & $-1.3752(12.91)$ & $-.9277(11.65)$ & $-.9437(9.71)$ \\
\hline Household size & $-.0107(1.12)$ & $-.0141(1.20)$ & $.0170(1.96)$ & $.0083(0.78)$ \\
\hline \# children & $.0161(1.63)$ & $.0163(1.36)$ & $.0276(3.08)$ & $.0298(2.73)$ \\
\hline Primary education & $.3500(5.11)$ & $.3451(4.19)$ & $.4321(6.94)$ & $.3784(5.04)$ \\
\hline Lower secondary & $.5313(7.64)$ & $.5548(6.63)$ & $.5820(9.21)$ & $.6065(7.95)$ \\
\hline Upper secondary & $.7295(10.54)$ & $.7708(9.26)$ & $.7424(11.80)$ & $.7650(10.08)$ \\
\hline Post-secondary & $.7552(9.79)$ & $.8331(8.98)$ & $.7991(11.40)$ & $.8369(9.89)$ \\
\hline Tertiary - first level & $.8703(11.96)$ & $.8874(10.13)$ & $.8149(12.33)$ & $.8074(10.11)$ \\
\hline Tertiary - advanced & $.9407(7.95)$ & $.8794(6.02)$ & $.8528(7.93)$ & $.8312(6.23)$ \\
\hline Employed on leave & $.0388(0.46)$ & $.0342(0.35)$ & $.0557(0.72)$ & $.0438(0.49)$ \\
\hline Unemployed $<12$ mths & $-.9621(13.19)$ & $-.9096(10.44)$ & $-.6537(9.84)$ & $-.6811(8.56)$ \\
\hline
\end{tabular}




$\begin{array}{lcccc}\text { Unemployed } \geq 12 \mathrm{mths} & -1.2738(20.63) & -1.2388(17.18) & -.8331(14.83) & -.8243(12.54) \\ \text { Disabled } & -1.1722(16.63) & -1.1532(14.23) & -1.0599(16.52) & -1.0340(13.99) \\ \text { Retired } & -.0843(2.16) & -.0553(1.19) & -.0852(2.41) & -.0673(1.59) \\ \text { Homemaker } & -.0380(0.90) & -.0130(0.25) & -.0668(1.75) & -.0711(1.48) \\ \text { Student } & .2282(3.97) & .2476(3.37) & .1561(2.98) & .1346(2.01) \\ \text { Separated/divorced } & -.3456(7.16) & -.2988(5.23) & -.3459(7.88) & -.2943(5.65) \\ \text { Widowed } & -.2612(5.16) & -.1857(3.10) & -.3675(7.99) & -.3050(5.58) \\ \text { Married } & .4651(12.63) & .4808(10.79) & .5828(17.41) & .6318(15.55) \\ \text { Internet daily } & .5177(15.67) & .5250(13.02) & .4067(13.54) & .4004(10.89) \\ \text { Internet } / \text { week } & .4621(11.86) & .4625(9.69) & .3238(9.13) & .3555(8.17) \\ \text { Internet occasionally } & .3432(9.06) & .3909(8.47) & .2489(7.23) & .2908(6.91) \\ \text { Religion every day } & .4430(5.09) & .4895(4.71) & .3565(4.50) & .3909(4.13) \\ \text { Religion >once/week } & .3778(6.21) & .4404(6.04) & .2789(5.03) & .3133(4.71) \\ \text { Religion once a week } & .3600(9.94) & .3765(8.59) & .2782(8.46) & .2573(6.44) \\ \text { Religion 1 or 2/month } & .1815(4.66) & .1781(3.78) & .1808(5.10) & .1864(4.34) \\ \text { Religion few/year } & .1497(4.95) & .1546(4.28) & .1381(5.03) & .1281(3.89) \\ \text { Religion once year } & .0499(1.15) & .0823(1.61) & .0326(0.82) & .0651(1.40) \\ \text { Religion <1 year } & -.0195(0.52) & -.0164(0.37) & -.0384(1.12) & -.0317(0.77) \\ \text { Village/small town } & .0667(1.93) & .0415(1.00) & -.0006(0.02) & -.0231(0.61) \\ \text { Medium town } & .0160(0.43) & -.0220(0.50) & -.0163(0.48) & -.0177(0.44) \\ \text { City/suburb } & -.0657(1.77) & -.0841(1.88) & -.0092(0.28) & -.0117(0.29) \\ \text { Citizen } & .2600(4.40) & .2714(3.73) & .1907(3.55) & .2120(3.19) \\ \text { Household Income }(\text { euros) }) & .000030(5.79) & & .000018(3.66) \\ \text { Constant } & 6.5799 & 6.4326 & 7.0638 & 7.0361 \\ \text { N } & 34,791 & 24,444 & 34704 & 24,424 \\ \text { Adjusted R }{ }^{2} & .2261 & .2458 & .1890 & .2024\end{array}$

Base categories: Austria; attends religious events never; internet never; employed; single; no education and countryside. T-statistics in parentheses.

Wordings:

Q1. All things considered, how satisfied would you say you are with your life these days? Please tell me on a scale of 1 to 10, where 1 means very dissatisfied and 10 means very satisfied. Mean(SD) $=6.89(2.17)$

Q2. Taking all things together on a scale of 1 to 10, how happy would you say you are? Here 1 means you are very unhappy and 10 means you are very happy. $\operatorname{Mean}(\mathrm{SD})=7.33(1.92)$ 
Table 5. International Happiness Equations using Data from the 2007 International Social Survey Programme (ISSP)

\begin{tabular}{|c|c|c|c|}
\hline & All & Males & Females \\
\hline Age & $-.0231(18.77)$ & $-.0251(13.49)$ & $-.0216(13.09)$ \\
\hline $\mathrm{Age}^{2}$ & $.0002(16.17)$ & $.0002(11.66)$ & $.0002(11.24)$ \\
\hline Male & $-.0053(0.78)$ & & \\
\hline Lowest qualification & $-.0198(1.03)$ & $-.0177(0.60)$ & $-.0145(0.57)$ \\
\hline Above lowest & $.0443(2.31)$ & $.0140(0.48)$ & $.0735(2.87)$ \\
\hline Higher secondary & $.1053(5.50)$ & $.0857(2.93)$ & $.1307(5.13)$ \\
\hline Above higher secondary & $.0993(5.05)$ & $.0476(1.59)$ & $.1525(5.81)$ \\
\hline University degree & $.1567(7.91)$ & $.1216(4.06)$ & $.1993(7.49)$ \\
\hline Married & $.2046(21.88)$ & $.2145(15.64)$ & $.1907(14.75)$ \\
\hline Widowed & $-.0847(5.57)$ & $-.1379(5.00)$ & $-.0624(3.28)$ \\
\hline Divorced & $-.0163(1.09)$ & $-.0585(2.46)$ & $.0055(0.29)$ \\
\hline Separated & $-.0746(3.46)$ & $-.0847(2.47)$ & $-.0686(2.47)$ \\
\hline Civil partnership & $.1119(2.53)$ & $.1770(2.60)$ & $.0675(1.16)$ \\
\hline Employed part-time & $-.0387(3.35)$ & $-.0768(3.85)$ & $-.0212(1.46)$ \\
\hline Employed<part-time & $-.0584(2.48)$ & $-.1025(2.90)$ & $-.0255(0.81)$ \\
\hline Helping family member & $-.0233(0.70)$ & $-.0369(0.63)$ & $-.0126(0.31)$ \\
\hline Unemployed & $-.1857(13.81)$ & $-.2373(11.96)$ & $-.1391(7.55)$ \\
\hline Student & $.0351(2.19)$ & $.0461(1.99)$ & $.0292(1.32)$ \\
\hline Retired & $-.0399(3.19)$ & $-.0432(2.33)$ & $-.0359(2.09)$ \\
\hline Home worker & $.0060(0.48)$ & $-.1685(2.41)$ & $.0276(1.97)$ \\
\hline Permanently disabled & $-.2674(10.87)$ & $-.3283(9.25)$ & $-.2093(6.14)$ \\
\hline Other LF & $-.0295(1.09)$ & $-.0474(1.05)$ & $-.0041(0.12)$ \\
\hline No religion & $-.0544(6.43)$ & $-.0659(5.57)$ & $-.0443(3.66)$ \\
\hline Argentina & $-.0387(1.70)$ & $.0168(0.50)$ & $-.0859(2.79)$ \\
\hline Austria & $-.0693(2.75)$ & $-.0630(1.69)$ & $-.0729(2.14)$ \\
\hline Belgium & $.0181(0.77)$ & $.0681(2.05)$ & $-.0319(0.98)$ \\
\hline Bulgaria & $-.4958(19.33)$ & $-.4840(12.61)$ & $-.5097(14.79)$ \\
\hline Chile & $-.1146(5.10)$ & $-.0738(2.15)$ & $-.1498(5.03)$ \\
\hline Taiwan & $-.1486(7.42)$ & $-.1258(4.39)$ & $-.1647(5.86)$ \\
\hline Croatia & $-.3718(15.28)$ & $-.3111(8.80)$ & $-.4256(12.70)$ \\
\hline Cyprus & $-.1925(7.53)$ & $-.1344(3.70)$ & $-.2504(6.98)$ \\
\hline Czech Republic & $-.0216(0.87)$ & $.0263(0.72)$ & $-.0578(1.71)$ \\
\hline Dominican Republic & $-.0205(0.89)$ & $.0637(1.86)$ & $-.0889(2.84)$ \\
\hline Finland & $-.2285(9.70)$ & $-.2065(5.89)$ & $-.2477(7.80)$ \\
\hline France & $-.3285(16.06)$ & $-.2763(9.23)$ & $-.3777(13.50)$ \\
\hline Germany & $-.1186(5.49)$ & $-.1383(4.43)$ & $-.0976(3.26)$ \\
\hline Ireland & $.2196(10.81)$ & $.2706(9.01)$ & $.1724(6.25)$ \\
\hline Israel & $-.2140(9.14)$ & $-.1846(5.61)$ & $-.2405(7.21)$ \\
\hline Japan & $-.1758(7.18)$ & $-.2044(5.74)$ & $-.1598(4.74)$ \\
\hline South Korea & $-.3483(15.56)$ & $-.3335(10.21)$ & $-.3586(11.68)$ \\
\hline Latvia & $-.4257(16.64)$ & $-.3290(8.47)$ & $-.4957(14.57)$ \\
\hline Mexico & $.1559(6.77)$ & $.1704(5.05)$ & $.1428(4.53)$ \\
\hline New Zealand & $.0754(2.91)$ & $.0830(2.21)$ & $.0698(1.95)$ \\
\hline
\end{tabular}




$\begin{array}{lccl}\text { Norway } & .0161(0.65) & .0445(1.23) & -.0089(0.26) \\ \text { Philippines } & -.1409(5.86) & -.1554(4.54) & -.1224(3.63) \\ \text { Poland } & -.1171(4.97) & -.0602(1.77) & -.1674(5.14) \\ \text { Russia } & -.6096(28.87) & -.4909(14.66) & -.6870(24.98) \\ \text { Slovakia } & -.3553(14.44) & -.3398(8.95) & -.3676(11.34) \\ \text { Slovenia } & -.2504(9.51) & -.2318(6.08) & -.2639(7.26) \\ \text { South Africa } & -.0665(3.39) & -.0461(1.59) & -.0887(3.33) \\ \text { Sweden } & -.0535(2.26) & -.0437(1.28) & -.0585(1.78) \\ \text { Switzerland } & .1677(6.55) & .1562(4.07) & .1753(5.10) \\ \text { Great Britain } & .0844(2.82) & .0043(0.09) & .1313(3.34) \\ \text { USA } & .0939(4.29) & .0942(2.84) & .0919(3.14) \\ \text { Uruguay } & -.0344(1.52) & .0118(0.34) & -.0731(2.44) \\ \text { Constant } & 3.6352 & 3.6804 & 3.5861 \\ \text { N } & 44,953 & 20,158 & 24,795 \\ \text { Adjusted } \mathrm{R}^{2} & .1235 & .1156 & .1336\end{array}$

Source: ISSP 2007.

Dependent variable mean $=3.07 \mathrm{SD}=0.711$. Males $=3.08(0.70)$ and females $=3.06(0.72)$

Base categories: Australia; no qualifications; never married and employed full-time. T-statistics in parentheses.

The International Social Science Survey (ISSP), asks: "If you were to consider your life in general these days, how happy or unhappy would you say you are, on the whole? [4] Very happy; [3] Fairly happy; [2] Not very happy; [1] Not at all happy." 
Table 6. Recent Changes in European Life Satisfaction, 2007-2010

\begin{tabular}{|c|c|c|c|}
\hline & May 2010 & Jan-Feb 2009 & Sept-Oct 2007 \\
\hline Age 15-24 & $.3010(14.39)$ & $.1886(9.00)$ & $.2544(11.60)$ \\
\hline Age $25-34$ & $.1388(9.38)$ & $.1035(6.88)$ & $.1296(8.76)$ \\
\hline Age $35-44$ & $.0644(4.67)$ & $.0485(3.53)$ & $.0419(3.05)$ \\
\hline Age 55-64 & $.0483(3.25)$ & $.0578(3.93)$ & $.0391(2.63)$ \\
\hline Age $\geq 65$ & $.1595(8.75)$ & $.1615(9.01)$ & $.1245(6.90)$ \\
\hline Male & $-.0386(4.52)$ & $-.0253(2.95)$ & $-.0143(1.67)$ \\
\hline $\mathrm{ALS} \leq 16$ & $-.2773(20.51)$ & $-.2591(19.42)$ & $-.2440(18.81)$ \\
\hline ALS 16-19 & $-.1646(15.59)$ & $-.1372(13.05)$ & $-.1370(13.08)$ \\
\hline No FT education & $-.4448(9.81)$ & $-.2650(6.07)$ & $-.2871(3.60)$ \\
\hline Home keeper & $-.0944(5.48)$ & $-.0458(2.76)$ & $-.0349(2.15)$ \\
\hline Student & $.0124(0.56)$ & $.0300(1.34)$ & $.0307(1.34)$ \\
\hline Unemployed & $-.4069(27.64)$ & $-.3486(22.03)$ & $-.3043(17.09)$ \\
\hline Retired & $-.0906(6.07)$ & $-.0903(6.12)$ & $-.0857(5.78)$ \\
\hline Living as married & $-.0750(4.74)$ & $-.0619(3.64)$ & $-.0975(8.28)$ \\
\hline Single & $-.1496(11.42)$ & $-.0750(4.88)$ & $-.1308(10.44)$ \\
\hline Divorced/separated & $-.2504(15.16)$ & $-.2500(12.00)$ & $-.2332(16.33)$ \\
\hline Widow & $-.1965(12.20)$ & $-.1649(10.81)$ & $-.2528(14.31)$ \\
\hline Austria & $-.0280(0.89)$ & $-.1377(4.41)$ & $-.0802(2.61)$ \\
\hline Bulgaria & $-.9399(29.60)$ & $-.9349(29.41)$ & $-1.0022(31.65)$ \\
\hline Croatia & $-.2815(8.85)$ & $-.1971(6.33)$ & $-.3453(11.04)$ \\
\hline Cyprus & $-.0789(2.05)$ & $-.0194(0.51)$ & $-.1251(3.32)$ \\
\hline Czech Republic & $-.2636(8.37)$ & $-.2450(7.95)$ & $-.2704(8.96)$ \\
\hline Denmark & $.4808(15.17)$ & .4707 (15.10) & $.4177(13.52)$ \\
\hline East Germany & $-.2940(7.56)$ & $-.2879(7.65)$ & $-.4240(11.37)$ \\
\hline Estonia & $-.3722(11.79)$ & $-.3730(12.01)$ & $-.3743(12.19)$ \\
\hline Finland & $.1302(4.13)$ & $.1109(3.58)$ & $.0394(1.29)$ \\
\hline France & $-.1451(4.63)$ & $-.2345(7.61)$ & $-.2078(6.84)$ \\
\hline Greece & $-.8722(27.75)$ & $-.6832(21.91)$ & $-.4928(16.00)$ \\
\hline Hungary & $-.6835(21.72)$ & $-.7234(23.31)$ & $-.7127(23.09)$ \\
\hline Iceland & $.3225(8.47)$ & & \\
\hline Ireland & $.1406(4.45)$ & $.1694(5.41)$ & $.0222(0.72)$ \\
\hline Italy & $-.3938(12.51)$ & $-.5326(17.27)$ & $-.3644(11.72)$ \\
\hline Latvia & $-.5400(17.14)$ & $-.6549(21.05)$ & $-.5125(16.65)$ \\
\hline Lithuania & $-.6769(21.56)$ & $-.6978(22.52)$ & $-.5541(17.97)$ \\
\hline Luxembourg & $.1959(5.09)$ & $.2402(6.33)$ & $.1946(5.16)$ \\
\hline Macedonia & $-.5504(17.49)$ & $-.5426(17.37)$ & $-.5873(18.83)$ \\
\hline Malta & $-.1562(4.00)$ & $-.0560(1.45)$ & $-.1578(4.15)$ \\
\hline Netherlands & $.2175(6.93)$ & 3067 (9.99) & $.2321(7.58)$ \\
\hline Poland & $-.2428(7.65)$ & $-.3374(10.81)$ & $-.2974(9.55)$ \\
\hline Portugal & $-.7540(23.66)$ & $-.6865(21.58)$ & $-.6419(20.37)$ \\
\hline Romania & $-1.0652(33.89)$ & $-.6638(21.47)$ & $-.8028(25.79)$ \\
\hline Slovakia & $-.2814(8.95)$ & $-.3755(12.10)$ & $-.4412(14.66)$ \\
\hline Slovenia & $-.0979(3.12)$ & $-.0710(2.28)$ & $-.0846(2.73)$ \\
\hline
\end{tabular}




$\begin{array}{lccc}\text { Spain } & -.1428(4.50) & -.1499(4.79) & -.1036(3.26) \\ \text { Sweden } & .2747(8.79) & .2957(9.53) & .1778(5.76) \\ \text { Turkey } & -.3812(11.64) & -.5026(15.72) & -.2549(7.82) \\ \text { Turkish Cyprus } & -.4080(10.46) & -.4793(12.53) & -.4136(10.71) \\ \text { United Kingdom } & .2438(8.22) & .1600(5.48) & .1051(3.65) \\ \text { West Germany } & -.0294(4.85) & -.0733(2.36) & -.1149(3.75) \\ \text { Constant } & 3.2968 & 3.2609 & 3.3261 \\ & & & \\ \text { Adjusted } \mathrm{R}^{2} & .2971 & .2688 & .2346 \\ \mathrm{~N} & 30,580 & 30,017 & 29,085\end{array}$

Source: Eurobarometers \#68.1, \#71.1 and \#73.4.

Notes: excluded categories Belgium; married; ages 45-54; employed and age left school $\geq 20$. T-statistics in parentheses.

The Eurobarometer asks; 'On the whole how satisfied are you very satisfied(=4); fairly satisfied (=3); not very satisfied (=2) or not at all satisfied (=1) with the life you lead?'

Mean scores are below.

$\begin{array}{llll} & 2010 & 2009 & 2007 \\ \text { Austria } & 3.07 & 2.93 & 3.07 \\ \text { Belgium } & 3.13 & 3.12 & 3.18 \\ \text { Bulgaria } & 2.17 & 2.18 & 2.15 \\ \text { Croatia } & 2.81 & 2.87 & 2.81 \\ \text { Cyprus } & 3.06 & 3.13 & 3.05 \\ \text { Czech Republic } & 2.86 & 2.86 & 2.91 \\ \text { Denmark } & 3.66 & 3.64 & 3.65 \\ \text { East Germany } & 2.75 & 2.78 & 2.70 \\ \text { Estonia } & 2.77 & 2.74 & 2.80 \\ \text { Finland } & 3.30 & 3.29 & 3.25 \\ \text { France } & 2.98 & 2.86 & 2.97 \\ \text { Greece } & 2.24 & 2.42 & 2.68 \\ \text { Hungary } & 2.38 & 2.31 & 2.38 \\ \text { Iceland } & 3.57 & & \\ \text { Ireland } & 3.24 & 3.28 & 3.21 \\ \text { Italy } & 2.72 & 2.56 & 2.79 \\ \text { Latvia } & 2.59 & 2.43 & 2.68 \\ \text { Lithuania } & 2.44 & 2.41 & 2.63 \\ \text { Luxembourg } & 3.36 & 3.37 & 3.39 \\ \text { Macedonia } & 2.49 & 2.51 & 2.54 \\ \text { Malta } & 2.93 & 3.05 & 3.02 \\ \text { Netherlands } & 3.41 & 3.44 & 3.44 \\ \text { Poland } & 2.88 & 2.76 & 2.85 \\ \text { Portugal } & 2.29 & 2.31 & 2.47 \\ \text { Romania } & 2.08 & 2.46 & 2.39 \\ \text { Slovakia } & 2.85 & 2.74 & 2.74 \\ \text { Slovenia } & 3.04 & 3.03 & 3.10 \\ \text { Spain } & 2.90 & 2.91 & 3.07 \\ \text { Sweden } & 3.44 & 3.47 & 3.38 \\ \text { Turkey } & 2.70 & 2.58 & 2.87 \\ \text { Turkish Cyprus } & 2.76 & 2.66 & 2.82 \\ \text { United Kingdom } & 3.32 & 3.23 & 3.22 \\ \text { West Germany } & 3.10 & 3.02 & 3.05 \\ & & & \end{array}$


Table 7. Job Satisfaction Equations for the USA, 1972-2008

(1) (2) (3)

$\begin{array}{lcccc}\text { Age } & .0084(24.12) & .0077(16.25) & .0073(11.45) & .0073(13.85) \\ \text { Male } & -.0345(3.69) & -.0422(3.47) & -.0371(2.29) & -.0574(4.34) \\ \text { Self-employed } & .2000(14.55) & .1636(8.95) & .1722(7.12) & .1674(8.46) \\ \text { Black } & -.1701(12.24) & -.1447(7.98) & -.1496(5.91) & -.1474(7.57) \\ \text { Other non-white } & -.0419(1.91) & -.0346(1.26) & -.0151(0.41) & -.0267(0.91) \\ \text { Time } & -.0015(3.27) & -.0019(2.89) & -.0009(0.96) & -.0035(4.52) \\ \text { \#Years of schooling } & .0140(8.64) & .0069(3.20) & .0075(2.58) & .0016(0.68) \\ \text { Part-time } & -.0909(5.55) & -.0909(5.55) & -.0805(3.69) & -.0313(1.57) \\ \text { Union member } & & & -.0296(1.30) & \\ \text { Lose job fairly likely } & & -.0055(0.15) & -.0077(0.16) & -.0270(0.69) \\ \text { Lose job not too likely } & & .1293(4.37) & .1147(2.87) & .1088(3.41) \\ \text { Lose job not at all likely } & & .2979(10.53) & .2815(7.38) & .2672(8.76) \\ \text { Lose job - go OLF } & & -.6413(1.90) & \mathrm{n} / \mathrm{a} & -.4402(1.17) \\ \text { Find job somewhat easy } & & -.0898(5.79) & -.0787(3.83) & -.0934(5.69) \\ \text { Find job not easy at all } & & -.1079(7.10) & -.0904(4.45) & -.1243(7.70) \\ \text { Log of annual pay } & & & & .0453(5.92) \\ \text { Constant } & 2.8337 & 2.7845 & 2.8007 & 2.4720 \\ & & & & \\ \text { Adjusted R } & & .0618 & .0582 & .0621 \\ \text { N } & .0414 & 16,155 & 9,177 & 14,390\end{array}$

This table uses data on current workers. The losing- and finding-a-job variables are not available in years 19721976, 1980, 1984 and 1987. Union status is not available in 1972, 1974, $1977 \& 1982$. Base categories are losejob-is-very-likely and find-job-is-very-easy. Equations also include 8 region-dummies.

T-statistics in parentheses. Mean job satisfaction(SD) $=3.29(0.81)$ 
Table 8. Job Satisfaction Through Time in the USA, 1972-2008

Question: On the whole how satisfied are you with the work you do - would you say you are very satisfied, moderately satisfied, a little dissatisfied, or very dissatisfied?

All

Very satisfied

Moderately satisfied

A little dissatisfied

Very dissatisfied

$\mathrm{N}$

All

Very satisfied

Moderately satisfied

A little dissatisfied

Very dissatisfied

$\mathrm{N}$

All

Very satisfied

Moderately satisfied

A little dissatisfied

Very dissatisfied

$\mathrm{N}$

Source: General Social Surveys

\section{4}

$\begin{array}{rrrrrrrrrrr}49 \% & 50 & 50 & 56 & 53 & 49 & 52 & 47 & 48 & 53 & 47 \\ 37 & 37 & 38 & 33 & 33 & 39 & 37 & 37 & 39 & 35 & 35 \\ 11 & 8 & 8 & 8 & 9 & 10 & 8 & 12 & 9 & 8 & 12 \\ 3 & 4 & 4 & 3 & 5 & 2 & 4 & 4 & 5 & 4 & 6 \\ 864 & 775 & 737 & 748 & 741 & 867 & 850 & 821 & 1,009 & 897 & 875\end{array}$

19851986198719881989199019911993199419961998

$\begin{array}{rrrrrrrrrrr}49 & 49 & 46 & 48 & 48 & 48 & 46 & 44 & 47 & 46 & 48 \\ 38 & 40 & 38 & 40 & 38 & 39 & 42 & 42 & 40 & 40 & 39 \\ 10 & 9 & 11 & 10 & 10 & 10 & 8 & 10 & 11 & 11 & 10 \\ 3 & 2 & 4 & 3 & 4 & 4 & 4 & 4 & 3 & 4 & 3 \\ 903 & 838 & 1,132 & 889 & 911 & 847 & 882 & 975 & 1,903 & 1,935 & 1,869 \\ \mathbf{2 0 0 0} & \mathbf{2 0 0 2} 2004 & \mathbf{2 0 0 6} \mathbf{2 0 0 8} & \text { All } & & & & & \end{array}$

$\begin{array}{rrrrrc}45 & 51 & 51 & 49 & 51 & 48 \\ 44 & 37 & 37 & 38 & 38 & 39 \\ 9 & 8 & 8 & 9 & 8 & 10 \\ 3 & 4 & 4 & 4 & 2 & 4 \\ 1,820 & 871 & 1,162 & 1,799 & 1,204 & 29,124\end{array}$


Figure 1. Human Development Index and Happiness in Western Europe, 2007

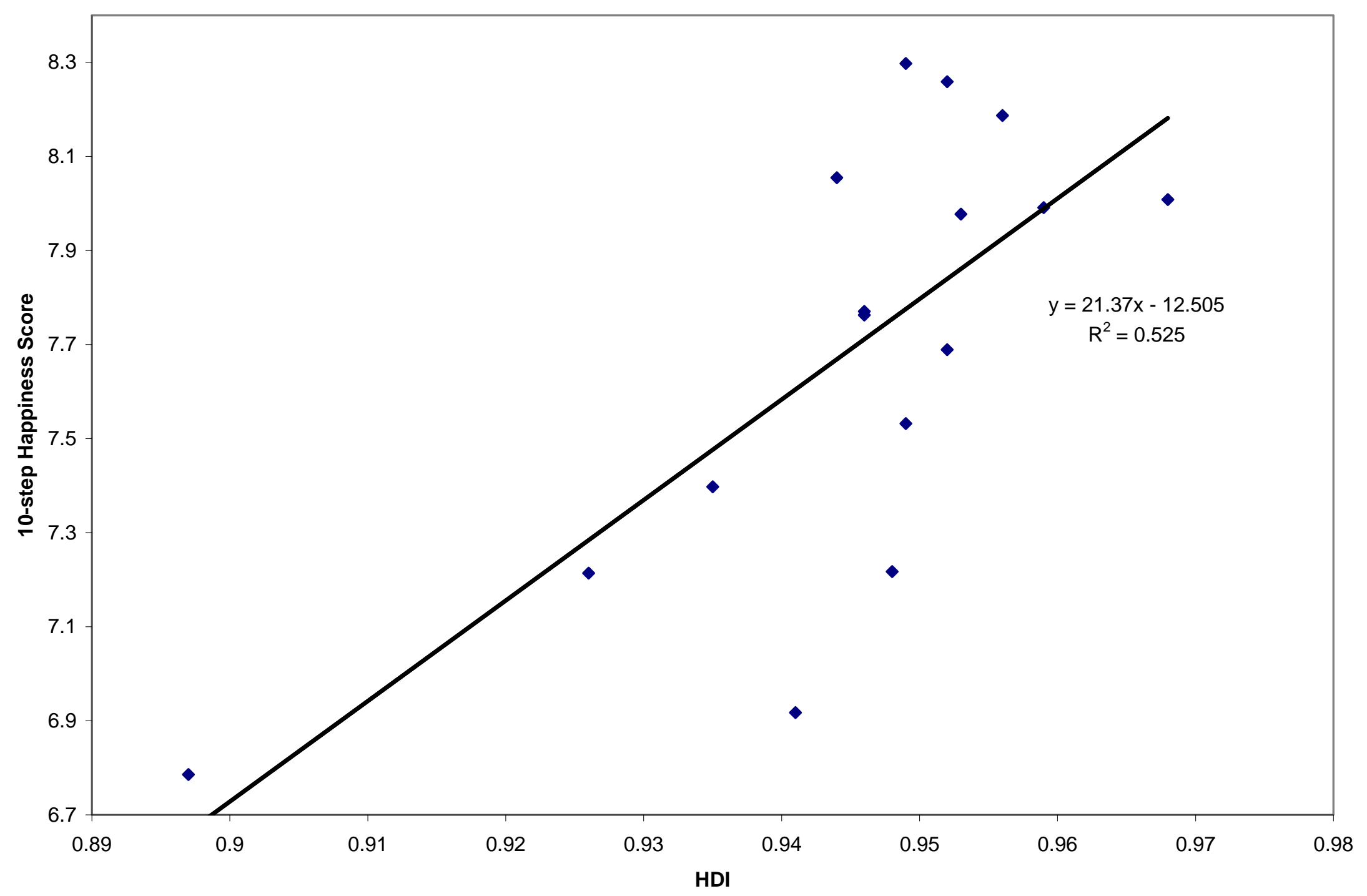


Figure 2. The U-shape in age in life satisfaction in Europe, 1973-2009. No personal controls

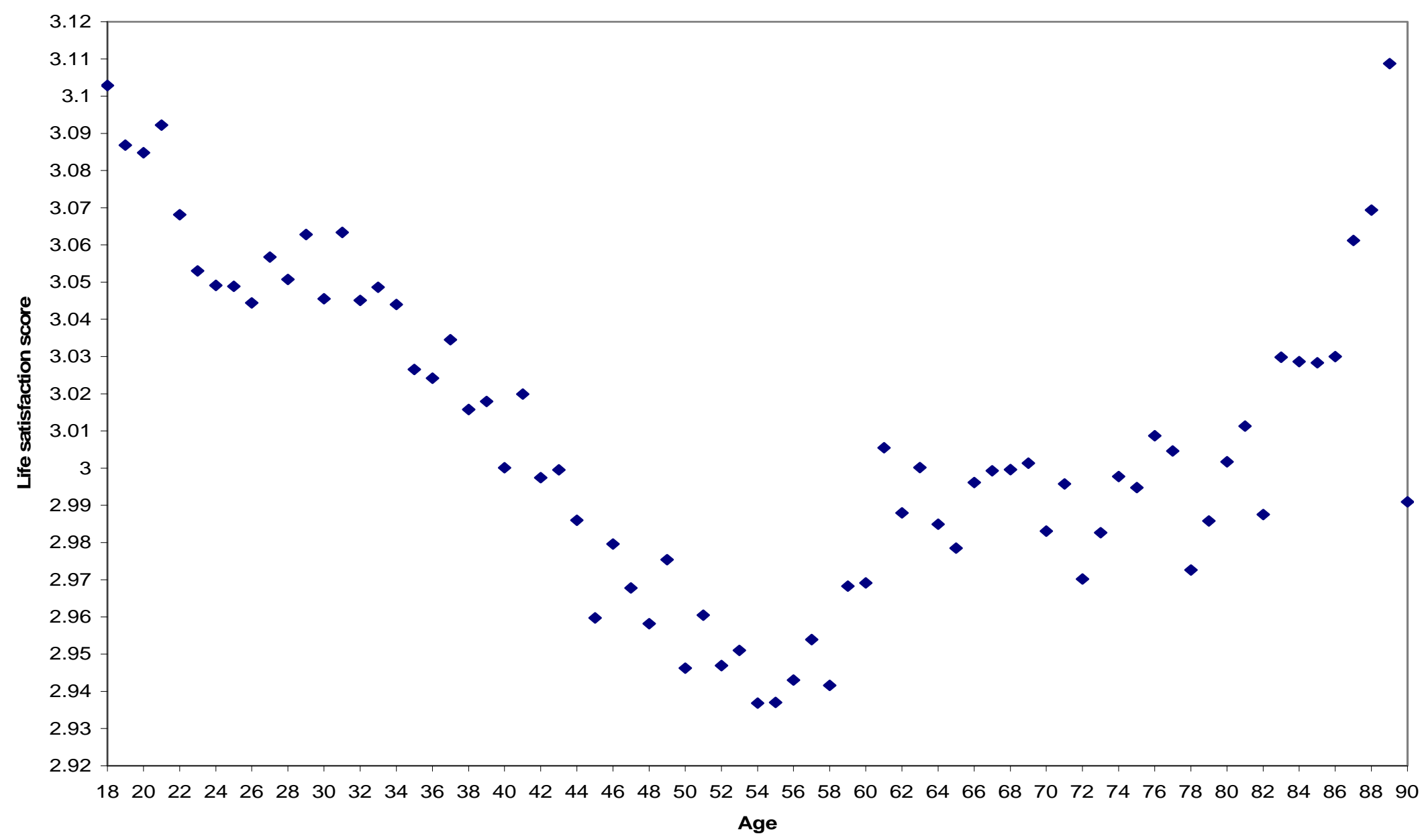

